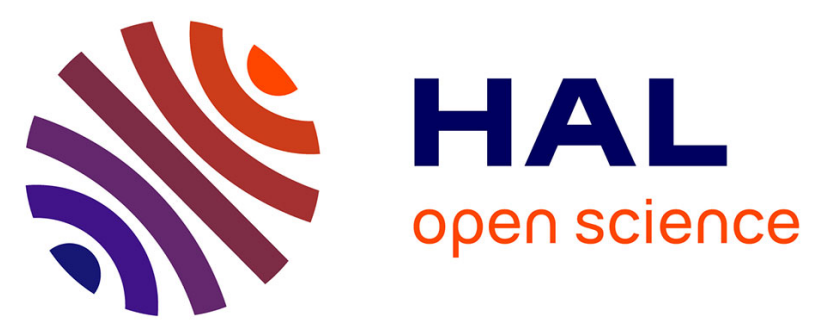

\title{
Climatology of Fine and Coarse Mode Aerosol Optical Thickness Over East and South Asia Derived From POLDER/PARASOL Satellite
}

Lei Li, Huizheng Che, Yevgeny Derimian, Oleg Dubovik, Qingzu Luan, Qiuyue Li, Xueying Huang, Hujia Zhao, Ke Gui, Yu Zheng, et al.

\section{To cite this version:}

Lei Li, Huizheng Che, Yevgeny Derimian, Oleg Dubovik, Qingzu Luan, et al.. Climatology of Fine and Coarse Mode Aerosol Optical Thickness Over East and South Asia Derived From POLDER/PARASOL Satellite. Journal of Geophysical Research: Atmospheres, 2020, 125 (16), 10.1029/2020JD032665 . hal-03004939

\section{HAL Id: hal-03004939 \\ https://hal.science/hal-03004939}

Submitted on 20 Apr 2021

HAL is a multi-disciplinary open access archive for the deposit and dissemination of scientific research documents, whether they are published or not. The documents may come from teaching and research institutions in France or abroad, or from public or private research centers.
L'archive ouverte pluridisciplinaire HAL, est destinée au dépôt et à la diffusion de documents scientifiques de niveau recherche, publiés ou non, émanant des établissements d'enseignement et de recherche français ou étrangers, des laboratoires publics ou privés. 


\section{JGR Atmospheres}

\section{RESEARCH ARTICLE 10.1029/2020JD032665 \\ Key Points: \\ Climatology of Fine and Coarse Mode Aerosol Optical Thickness Over East and South Asia Derived From POLDER/PARASOL Satellite}

- Aerosol optical thickness (AOT), fine mode AOT (fAOT), and coarse mode AOT (cAOT) are retrieved simultaneously by the component algorithm

- The satellite retrieved aerosol optical properties show a good agreement with AERONET products in Asia

- The climatological characteristics of AOT, fAOT, cAOT, and fine mode fraction (FMF) over East and South Asia are presented

Correspondence to:

H. Che and O. Dubovik,

chehz@cma.gov.cn;

oleg.dubovik@univ-lille.fr

Citation:

Li, L., Che, H., Derimian, Y., Dubovik, O., Luan, Q., Li, Q., et al. (2020). Climatology of fine and coarse mode aerosol optical thickness over East and South Asia derived from

POLDER/PARASOL satellite. Journal of Geophysical Research: Atmospheres, 125, e2020JD032665. https://doi.org/ 10.1029/2020JD032665

Received 24 MAR 2019 Accepted 25 JUN 2020 Accepted article online 29 JUN 2020

(C)2020. American Geophysical Union. All Rights Reserved.

\author{
Lei Li ${ }^{1}$, Huizheng Che ${ }^{1}$ (D), Yevgeny Derimian ${ }^{2}$, Oleg Dubovik ${ }^{2}$ (D), Qingzu Luan ${ }^{3,4}$, Qiuyue $\mathrm{Li}^{3,4}$, \\ Xueying Huang ${ }^{5}$, Hujia Zhao ${ }^{1,6}$, Ke Gui ${ }^{1}$ (D), Yu Zheng ${ }^{1}$, Linchang An ${ }^{1,7}$, Tianze Sun ${ }^{1}$, \\ and Yuanxin Liang ${ }^{1}$ \\ ${ }^{1}$ State Key Laboratory of Severe Weather (LASW) and Key Laboratory of Atmospheric Chemistry (LAC), Chinese \\ Academy of Meteorological Sciences, Beijing, China, ${ }^{2}$ University of Lille, CNRS, UMR 8518-LOA-Laboratoire d'Optique \\ Atmosphérique, Lille, France, ${ }^{3}$ Institute of Urban Meteorology, Beijing, China, ${ }^{4}$ Beijing Municipal Climate Centre, Beijing \\ Meteorological Bureau, Beijing, China, ${ }^{5}$ Tangxian Meteorological Bureau, Baoding, China, ${ }^{6}$ Institute of Atmospheric \\ Environment, Shenyang, China, ${ }^{7}$ National Meteorological Center, Beijing, China
}

\section{Introduction}

The aerosol effect on climate is mainly determined by anthropogenic particles as an external cause of climate change (Charlson et al., 1992; Hansen et al., 1997). The fine mode fraction (FMF) of aerosol optical thickness (AOT) is an indicator for distinguishing the anthropogenic aerosol (Bellouin et al., 2005). These submicron aerosols are mainly a result of combustion processes and differ from the coarse natural particles generated by erosions and sea spray suspension. Assessment of the fine mode aerosol contribution to the total aerosol loading is an essential step for quantifying the impact of anthropogenic activities on the Earth's climate, environment, and human health. Many studies showed that, for example, mortality, lung cancer, and respiratory system problems are related to small atmospheric particles (diameter $<2.5 \mu \mathrm{m}$ ) (Beelen et al., 2014; Pope et al., 2002, 2004).

It was demonstrated that aerosol properties derived from multiangular, multispectral, and polarized measurements can provide an enhanced characterization of aerosol and surface properties (e.g., Deuzé et al., 1993, 2001; Litvinov et al., 2011; Waquet et al., 2007, 2009). The multiangle polarized measurements can also better characterize aerosols over land (Cheng et al., 2011; Chowdhary et al., 2005; Deuzé et al., 2001; Dubovik et al., 2011; Hasekamp \& Landgraf, 2005). For instance, Cheng et al. (2012) used a lookup table of one fine and one coarse lognormal aerosol modes to retrieve AOT and FMF from POLDER/PARASOL observations. A shortcoming of this approach however was in constraining the fine and coarse lognormal modes by a cluster analysis based on the AERONET measurements. The approach thus was applied for only some test cases (clear, polluted, and dusty). Indeed, the AERONET FMF is often used to constrain and validate the satellite retrievals as not affected by underlying surface and has a high accuracy over land as over ocean (O'Neill et al., 2001, 2003). However, AERONET does not provide a global continuous coverage. The Generalized Retrieval of Atmosphere and Surface Properties (GRASP) algorithm (Dubovik et al., 2011, 2014) was developed to retrieve aerosol property from satellite polarimetric observations using statistical 
optimization method. It also employs the multipixel approach (Dubovik et al., 2011) that in particular substantially improves the retrievals over land.

It should be mentioned that the MODIS satellite AOT products are considered as reference satellite data and also provide the FMF. For example, MODIS AOT and FMF were employed to estimate aerosol anthropogenic component over ocean (Kaufman et al., 2005). A LookUp Table-based Spectral Deconvolution Algorithm (LUT-SDA) was developed for MODIS measurements to obtain FMF (Yan et al., 2017, 2019). However, because of the difficulty in distinguishing signals from aerosols and land surface in top of the atmosphere measurements (Diner et al., 2005; Hauser et al., 2005; Kokhanovsky et al., 2010; Lee \& Chung, 2013; Li et al., 2009; Mishchenko \& Geogdzhayev, 2007), the FMF retrieved over land remains uncertain (Levy et al., 2010).

The seasonal and interannual variabilities of aerosol optical properties are associated with large and diverse aerosol sources and different meteorological characteristics during the different seasons. The fine mode AOT (fAOT) is attributed to the presence of fine particles generated from anthropogenic sources, such as black carbon, organic aerosols, sulfate, and nitrate. Asia is largely developing region with high anthropogenic emissions, in which biofuel emissions play an important role (Woo et al., 2003). However, the measurements of the chemical, physical, and optical properties of Asian aerosols are sparse and rare on a large spatial and extended temporal scale. More efforts are needed to understand and estimate accurately the effects of anthropogenic and natural aerosol on climate in Asia and particularly over East and South Asia (ESA), where not only the high concentrations exist but also the optical properties can significantly vary between the fine and coarse modes, causing different impacts (Cheng et al., 2012). Trying better address this issue, the current study uses a recently developed and modified version of GRASP algorithm that includes retrievals of aerosol components in fine and coarse modes ( $\mathrm{Li}$ et al., 2019). We apply this algorithm to POLDER/PARASOL observations over ESA region to explore the retrievals of spectral AOT, fAOT, and FMF from polarized observations. We then characterize the temporal and spatial distributions of the AOTs and FMF in the ESA region.

\section{Data and Methodology}

\subsection{AERONET Products}

AERONET has several hundreds of Sun/sky scanning radiometers located at surface sites throughout the world (Holben et al., 1998, 2001). The radiometers provide direct Sun measurements in eight or nine spectral channels covering a spectral range from 340 to $1,640 \mathrm{~nm}$ and also measure sky radiances at four wavelengths $(440,675,870$, and $1,020 \mathrm{~nm})$. The measurements are processed to provide comprehensive aerosol optical products in the AERONET database to facilitate the characterization of aerosol properties and validate satellite retrievals with reliable monitoring of aerosol optical and microphysical properties. Version 3 (V3) of the AERONET product is used in this study. The cloud screening and quality control checks are fully automatic in the AERONET algorithm, and the AOT uncertainty is estimated to be from 0.01 to 0.02 (Eck et al., 1999; Giles et al., 2019). If the aerosol particle size distribution is assumed to be effectively bimodal, the extraction of the fine and coarse mode optical thickness from the spectral shape of the total AOT is achievable. The spectral curvature algorithm can be also employed to separate fine and coarse mode optical thickness, but it cannot be used to distinguish the coarse mode AOT from cloud particles (O'Neill et al., 2003). For instance, Arola et al. (2017) have used the AERONET spectral deconvolution algorithm Level 1 and 2 data to assess how the fAOT is enhanced in cloudy conditions. They demonstrated however that it is difficult to separate the fAOT enhancements in the AERONET spectral deconvolution algorithm because of in-cloud processing and hygroscopic growth. The fine and coarse modes separation in the AERONET algorithm is realized at an inflection point found in the inversion procedure, which is usually within the size interval from 439 to $992 \mathrm{~nm}$. The used FMF at $440 \mathrm{~nm}$ in this study is then calculated as FMF $=\mathrm{fAOT}(440 \mathrm{~nm}) / \mathrm{AOT}(440 \mathrm{~nm})$, where fAOT and AOT are the fine mode and total AOT, respectively, as provided in the standard AERONET product. The highly accurate ground-based AERONET measurements usually serve as a reference for validation of satellite-derived aerosol optical properties.

\subsection{POLDER Sensor Description}

POLDER is an aerosol sensor that consists of wide field-of-view imaging spectroradiometer designed to measure multispectral, multidirectional, and polarized radiances (Deuzé et al., 2001). POLDER/PARASOL 
measures the total radiance in six window channels (440, 490, 565, 670, 865, and 1,020 nm) and linear polarization in three of these channels $(490,670$, and $865 \mathrm{~nm}$ ), and it acquires up to 16 successive multiangle measurements of both the total and polarized solar radiance. The resolution of POLDER/PARASOL observed pixel is $5.3 \times 6.2 \mathrm{~km}^{2}$ at nadir.

As described in Zeng et al. (2011), the POLDER cloud detection algorithm employs the separated and independent threshold tests for each individual pixel in every viewing direction (Buriez et al., 1997; Parol et al., 1999). The tests are used to detect and confirm the cloudy or clear pixel. The estimation of oxygen absorption around $763 \mathrm{~nm}$ (Vanbauce et al., 1998), the polarized reflectance (Goloub et al., 1997; Goloub et al., 2000), and solar reflectance at 490 and $865 \mathrm{~nm}$ are used by the cloudy pixel tests. Three additional "clear" tests (i.e., a low reflectance test, a spectral reflectance variability test between 443 and $865 \mathrm{~nm}$, and an apparent pressure test) are employed to indicate a confident cloud-free surface when a pixel cannot pass the cloudy tests. Angular and spatial variability tests also can be used for a pixel that cannot pass all tests above and remains uncategorized (Zeng et al., 2011). Therefore, POLDER utilizes the strengths of its multipolarization and multidirectional capability to discriminate the cloudy or clear pixel in the inversion.

\subsection{Description of the GRASP/Component Approach}

GRASP is designed to retrieve detailed aerosol and surface reflectance properties from a variety of remote sensing data (Dubovik et al., 2011, 2014). It is also an open source code and is accessible online (at https://www.grasp-open.com).

The algorithm has two essential modules: "forward model" and "numerical inversion." The "forward model" quantitatively simulates the measured atmospheric radiation with given surface and aerosol property parameters. A statistically optimized fitting of observations is conducted by the multiterm least squares method (LSM) in "numerical inversion" module. A full description of the "forward model" and "numerical inversion" modules can be found in Dubovik et al. (2011). Here we only provide a general description of the GRASP/Component approach, which is developed to retrieve aerosol optical properties and aerosol component fractions assumed in fine and coarse modes, and the detailed description is provided in Li et al. (2019).

The formulation of the forward radiative transfer modeling in the presented approach is generally similar to the formulation of the standard GRASP algorithm with the ideas documented in the studies (Dubovik et al., 2002, 2006; Dubovik \& King, 2000) for modeling of the aerosol scattering matrices. Differently from the previous versions, in the current component approach the aerosol complex refractive indices used in the forward and inverse modeling are calculated from fractions of aerosol species with a predescribed refractive indices of each species assumed in the conversion model ( $\mathrm{Li}$ et al., 2019). The numerical inversion is implemented as the methodology described in Li et al. (2019) to infer aerosol properties in fine and coarse modes by the aerosol components assumed in these modes. In this new approach the fractions of the aerosol component in fine and coarse modes are presented as unknowns instead of the real and imaginary parts of complex refractive index. The fine particles include black carbon, brown carbon, nonabsorbing insoluble species representing fine dust, or organic carbon, nonabsorbing soluble species representing anthropogenic salts and aerosol water content. The coarse particles include absorbing insoluble species mainly representing iron oxides, nonabsorbing insoluble mainly representing the bulk dust material, nonabsorbing soluble species representing natural salts (e.g., sea salts) and aerosol water content. The selection of aerosol elements and the size resolved component is based on the examination of a series of sensitivity tests and stability of the inversion results (Li et al., 2019). Specifically, because of the difficulty in distinguishing between the aerosol species that have similar spectral signatures in the observational configurations, the size resolved component formulation was chosen. The aerosol refractive index required for the forward calculations is derived by the engaged aerosol species and their fractions under a given mixing rule. Maxwell-Garnett effective medium approximation, employed in numerous studies for inferring aerosol component from remote sensing measurements (Li et al., 2013, 2015, 2019; Schuster et al., 2005, 2009, 2016; Wang et al., 2013), is used to estimate aerosol refractive index in this study. The hygroscopic property and proportion of soluble inorganic species (e.g., ammonium nitrite, ammonium sulfate, and sea salt) and water are employed to compute the refractive index of the host, which is required by the Maxwell-Garnett equations. 

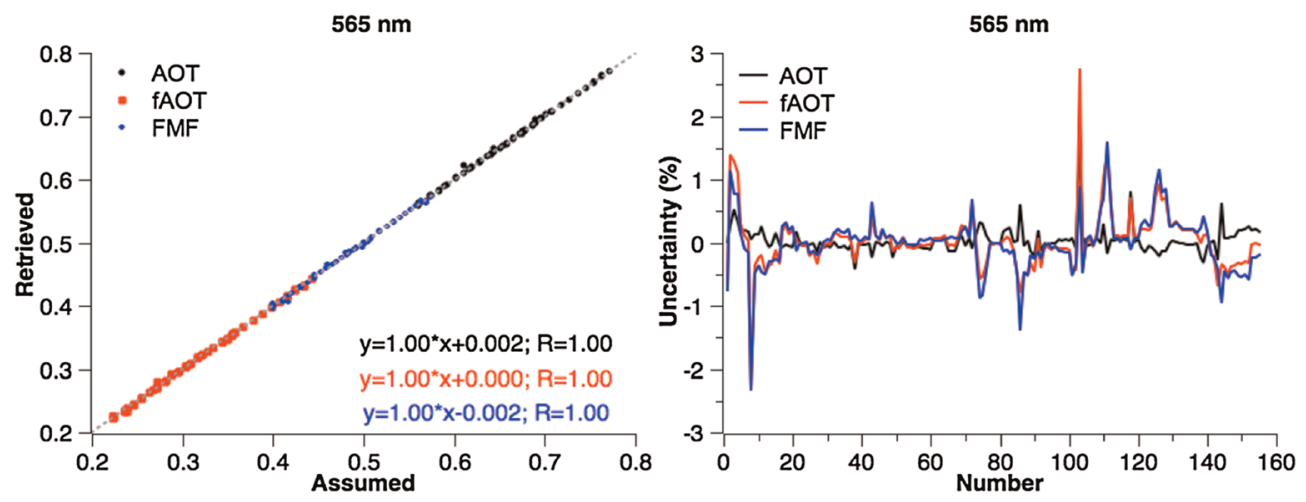

Figure 1. Assumed and retrieved aerosol optical thickness (AOT), fine mode aerosol optical thickness (fAOT), fine mode fraction (FMF), and their corresponding uncertainties at $565 \mathrm{~nm}$ in the sensitivity tests of GRASP/Component retrieval.

\subsection{Sensitivity and Uncertainty Tests for the GRASP/Component Approach}

The POLDER imager can collect rather comprehensive characterization of angular distribution of both total and polarized components of solar radiation. The completeness of such observations is significantly higher than most of passive satellite aerosol sensors. Meanwhile, the GRASP algorithm uses fully the high potential of spectral multiangular polarimetric observations to improve aerosol monitoring (Dubovik et al., 2011). A series of sensitivity tests had been performed to verify the performance and potential of the standard GRASP algorithm in the study of Dubovik et al. (2011). The results of tests showed the complete set of aerosol parameters can be robustly derived with acceptable accuracy (Dubovik et al., 2011). In this study, we show some additional sensitivity tests for the GRASP/Component approach.

For verification of the component algorithm performance, sensitivity tests were conducted by employing the synthetic POLDER/PARASOL measurements. Thus, first, the POLDER/PARASOL radiances and polarization measurements were simulated by the forward model calculations. Then, the synthetic measurements were inverted using the GRASP algorithm included the size-dependent aerosol component conversion model, which is incorporated with the Maxwell-Garnett mixing rule to calculate the aerosol component fractions. Examples of the assumed and retrieved AOT, fAOT, FMF, and their uncertainties at $565 \mathrm{~nm}$, based on the synthetic POLDER/PARASOL radiances and polarization measurements, are presented in Figure 1. It can be seen that the assumed and derived AOT, fAOT, and FMF are highly consistent, showing that the size fractions can be retrieved. Sensitivity study shows that the uncertainty for AOT is less than $1 \%$ and for fAOT and FMF is within 3\%. The statistics of the sensitivity test results for AOT, fAOT, and FMF at other wavelengths are presented in Table 1. The conducted tests demonstrated that the usage of the size-dependent Maxwell-Garnett conversion model allows the algorithm to retrieve AOT, fAOT, and FMF simultaneously.

\section{Results and Discussions}

\subsection{Intercomparisons of POLDER/PARASOL Retrievals and AERONET Measurements}

Essential validations of the optical characteristics retrieved from POLDER/PARASOL satellite observations using the GRASP/Component approach are presented in Li et al. (2019). The retrievals and residuals obtained by the GRASP/Component approach are in accordance with that obtained by the standard GRASP approach, and the aerosol optical characteristics are in reasonably good agreement with the standard AERONET product ( $\mathrm{Li}$ et al., 2019). More recently, the measurements of eight SONET sites for 10 months (from January to October in 2013) in China were used to validate and evaluate the products of the standard GRASP approach (Wei et al., 2020). Here we employ the measurements of 26 AERONET sites for 9 years (2005-2013) in Asia to validate the products of the GRASP/Component approach, which is different from the standard GRASP approach (Li et al., 2019, 2020). Figure 2 and Table 2 show the information about AERONET sites used in the current study for the validation of GRASP/Component products over ESA. According to the geographical location of sites and the considered season, aerosols at such sites can represent different types including mineral dust, biomass burning, urban, mixed, and background aerosol. The mean of the retrieved parameters for $2 \times 2$ pixels, centered at AERONET sites coordinates, is compared with the corresponding AERONET daily mean products. We screen the retrievals with the residual larger 
Table 1

Statistics of Intercomparison Between Assumed and Retrieved Parameters of the Sensitivity Tests of the GRASP/Component Approach

\begin{tabular}{|c|c|c|c|c|c|c|c|c|c|}
\hline & AOT & fAOT & FMF & AOT & fAOT & FMF & AOT & fAOT & FMF \\
\hline & $440 \mathrm{~nm}$ & & & $490 \mathrm{~nm}$ & & & $565 \mathrm{~nm}$ & & \\
\hline$A$ & 1.00 & 1.00 & 1.00 & 1.00 & 1.00 & 1.00 & 1.00 & 1.00 & 1.00 \\
\hline$B$ & 0.003 & 0.001 & -0.002 & 0.003 & 0.001 & -0.002 & 0.002 & 0.000 & -0.002 \\
\hline$R$ & 1.00 & 1.00 & 1.00 & 1.00 & 1.00 & 1.00 & 1.00 & 1.00 & 1.00 \\
\hline RMSE & 0.002 & 0.002 & 0.002 & 0.002 & 0.002 & 0.002 & 0.001 & 0.001 & 0.002 \\
\hline$M A E$ & 0.001 & 0.001 & 0.001 & 0.001 & 0.001 & 0.001 & 0.001 & 0.001 & 0.001 \\
\hline$M R E$ & $0.1 \%$ & $0.1 \%$ & $0.1 \%$ & $0.1 \%$ & $0.1 \%$ & $0.1 \%$ & $0.1 \%$ & $0.1 \%$ & $0.1 \%$ \\
\hline$S T D$ & 0.002 & 0.002 & 0.002 & 0.002 & 0.002 & 0.002 & 0.002 & 0.002 & 0.003 \\
\hline$U$ & $2.46 \%$ & $3.46 \%$ & $-1.48 \%$ & $2.19 \%$ & $3.18 \%$ & $-1.79 \%$ & $1.83 \%$ & $2.74 \%$ & $-2.35 \%$ \\
\hline \multirow[t]{2}{*}{$P$} & $<0.01$ & $<0.01$ & $<0.01$ & $<0.01$ & $<0.01$ & $<0.01$ & $<0.01$ & $<0.01$ & $<0.01$ \\
\hline & $675 \mathrm{~nm}$ & & & $870 \mathrm{~nm}$ & & & $1,020 \mathrm{~nm}$ & & \\
\hline A & 1.00 & 1.00 & 1.00 & 0.99 & 1.00 & 1.00 & 0.99 & 1.00 & 1.00 \\
\hline B & 0.002 & 0.000 & -0.001 & 0.003 & -0.000 & -0.001 & 0.003 & 0.000 & -0.001 \\
\hline$R$ & 1.00 & 1.00 & 1.00 & 1.00 & 1.00 & 1.00 & 1.00 & 1.00 & 1.00 \\
\hline RMSE & 0.001 & 0.001 & 0.002 & 0.001 & 0.001 & 0.002 & 0.001 & 0.000 & 0.001 \\
\hline$M A E$ & 0.001 & 0.001 & 0.001 & 0.001 & 0.000 & 0.001 & 0.001 & 0.000 & 0.001 \\
\hline$M R E$ & $0.1 \%$ & $0.1 \%$ & $0.1 \%$ & $0.2 \%$ & $0.2 \%$ & $0.2 \%$ & $0.2 \%$ & $0.2 \%$ & $0.2 \%$ \\
\hline$S T D$ & 0.002 & 0.002 & 0.003 & 0.003 & 0.002 & 0.003 & 0.004 & 0.002 & 0.003 \\
\hline$U$ & $1.45 \%$ & $2.16 \%$ & $-3.08 \%$ & $1.12 \%$ & $2.49 \%$ & $-4.24 \%$ & $1.08 \%$ & $2.83 \%$ & $-4.98 \%$ \\
\hline$P$ & $<0.01$ & $<0.01$ & $<0.01$ & $<0.01$ & $<0.01$ & $<0.01$ & $<0.01$ & $<0.01$ & $<0.01$ \\
\hline
\end{tabular}

Note. The values of slope $(A)$, intercept $(B)$, correlation coefficient $(R)$, root-mean-square error $(R M S E)$, mean absolute error $(M A E)$, mean relative error $(M R E)$, standard error deviation (STD), uncertainty $(U)$, and $P$ values are presented for aerosol optical thickness (AOT), fine mode aerosol optical thickness (fAOT), and fine mode fraction (FMF) at six wavelengths.

than $7 \%$, and the difference between the maximum and the minimum residual should be less than $5 \%$ for each site, consistently with the study of Wei et al. (2020). Figure 3 shows the intercomparisons of POLDER/PARASOL retrievals and AERONET products for AOT, fAOT, FMF, and Ångström exponent at all sites (in Table 2) over ESA during the period 2005-2013. It can be seen that the correlation coefficients are $\sim 0.9$ for AOT and fAOT. The statistics for AOT and fAOT at each site are presented in Table 3 except the BEY site due to a small number of available measurements. This intercomparison generally presents

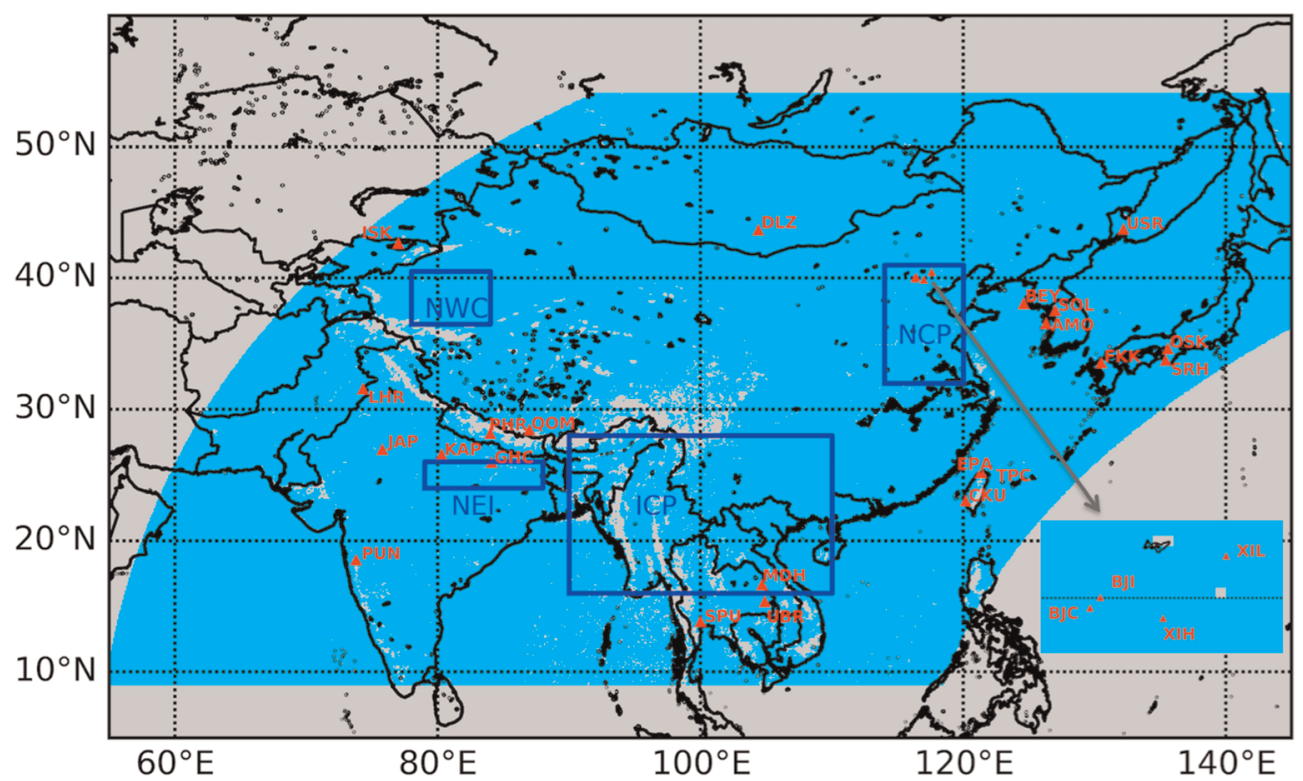

Figure 2. AERONET sites used in this study and the regions of interest: Indo-China Peninsula (ICP), North China Plain (NCP), Northeastern India (NEI), and Northwestern China (NWC). 
Table 2

AERONET Sites Used in This Study

\begin{tabular}{|c|c|c|c|c|}
\hline Site name & Lon $\left(^{\circ}\right)$ & Lat $\left(^{\circ}\right)$ & Alt (m) & Description \\
\hline Anmyon (AMO) & 126.33 & 36.54 & 47.0 & Rural site in a hilly region \\
\hline Baengnyeong (BEY) & 124.63 & 37.97 & 136.0 & Rural site surrounded by forest \\
\hline Beijing-CAMS (BJC) & 116.32 & 39.93 & 106.0 & Urban site \\
\hline Beijing-IAP (BJI) & 116.38 & 39.98 & 92.0 & Urban site \\
\hline Chen-Kung_Univ (CKU) & 120.20 & 22.99 & 50.0 & Urban site \\
\hline Dalanzadgad (DLZ) & 104.42 & 43.58 & $1,470.0$ & Rural site in dust region \\
\hline EPA-NCU (EPA) & 121.19 & 24.97 & 144.0 & Urban site \\
\hline Fukuoka (FKK) & 130.48 & 33.52 & 30.0 & Rural site (10 km away from city center) \\
\hline Gandhi_College (GHC) & 84.13 & 25.87 & 60.0 & Rural site with agricultural activity \\
\hline Issyk-Kul (ISK) & 76.98 & 42.62 & $1,650.0$ & Background site on a mountain \\
\hline Jaipur (JAP) & 75.81 & 26.91 & 450.0 & Urban site with pollution and dust \\
\hline Kanpur (KAP) & 80.23 & 26.51 & 123.0 & $17 \mathrm{~km}$ away from city center in Ganga basin \\
\hline Lahore (LHR) & 74.26 & 31.48 & 209.0 & Urban site with dust \\
\hline Mukdahan (MDH) & 104.68 & 16.61 & 166.0 & Rural site surrounded by forest and agriculture \\
\hline Osaka (OSK) & 135.59 & 34.65 & 50.0 & Urban site \\
\hline Pokhara (PHR) & 83.98 & 28.19 & 800.0 & Rural site in a valley with a monsoon convection \\
\hline Pune (PUN) & 73.81 & 18.54 & 595.0 & Rural site with hazy in winter \\
\hline QOMS_CAS (QOM) & 86.95 & 28.37 & $4,276.0$ & Background site on a mountain \\
\hline Seoul_SNU (SOL) & 126.95 & 37.46 & 116.0 & Urban site \\
\hline Shirahama (SRH) & 135.36 & 33.69 & 10.0 & Urban site \\
\hline Silpakorn_Univ (SPU) & 100.04 & 13.82 & 72.0 & Urban site \\
\hline Taipei_CWB (TPC) & 121.54 & 25.01 & 26.0 & Urban site \\
\hline Ubon_Ratchathani (UBR) & 104.87 & 15.25 & 120.0 & Urban site near airport \\
\hline Ussuriysk (USR) & 132.16 & 43.70 & 280.0 & Rural site \\
\hline XiangHe (XIH) & 116.96 & 39.75 & 36.0 & Rural site surrounded by agricultural fields \\
\hline Xinglong (XIL) & 117.58 & 40.40 & 899.0 & Rural site \\
\hline
\end{tabular}

good agreements between our satellite retrievals and the AERONET products. Note that the correlation coefficients for AOT and fAOT at DLZ, ISK, and QOM sites, located at 1,470, 1,650, and 4,276 m altitudes, are low most probably because the aerosol loadings are very low. These sites should be rather referred as a background. The validations of AOT and fAOT for different seasons are shown in Figure 4. It demonstrates that the agreement of GRASP/Component products with AERONET measurements is reasonably good for each season. Figure 3 also presents the GRASP/Component retrieved FMF at $440 \mathrm{~nm}$ and Ångström exponent $(870 / 440 \mathrm{~nm})$ versus those measured by AERONET. The correlations for FMF and Ångström exponent are also reasonably good ( $R$ of $\sim 0.8$ ) when the AOT at $440 \mathrm{~nm}$ is equal to or more than 0.2 with the residual less than $5 \%$. The root mean square error (RMSE $=0.13$ ) of FMF in this study is similar to that of FMF (RMSE $=0.18$ ) obtained by a new LUT-SDA version for Beijing, Hong Kong, and Osaka sites (Yan et al., 2019). The better agreement for Ångström exponent retrievals for higher AOT is known also for standard retrievals and other satellite products (Leeuw et al., 2015; Popp et al., 2016). Nevertheless, the good agreements ( $R$ of $~ 0.8-0.9$ ) for AOT, fAOT, FMF, and Ångström exponent show that the inversion of POLDER/PARASOL satellite measurements using the GRASP/Component approach is consistent with the ground-based AERONET reference in terms of aerosol optical properties.

\subsection{Monthly Variations of AOT, fAOT, and cAOT}

Figures 5-7 show the monthly averaged values of AOT, as well as fAOT and coarse mode AOT (cAOT) over ESA, as derived by the GRASP/Component approach from POLDER/PARASOL during the period March 2005 to November 2013. The retrievals are presented in a resolution of $0.1^{\circ} \times 0.1^{\circ}$. It is noted that the lack of retrievals in parts of India, Myanmar, and parts of southwest China in June, July, and August (JJA season) is attributed to persistent cloud cover during the monsoon season.

It can be seen that in Eastern and Central China, the Sichuan Basin, and Northeast India, the observed AOT has very high values (around 1.0) in the months of December, January, and February (DJF season) (Figure 5). Except the Tibetan Plateau region, the AOT is generally higher than 0.2 in the whole ESA region in the months of March, April, and May (MAM season). However, very high AOT values in the Taklimakan 

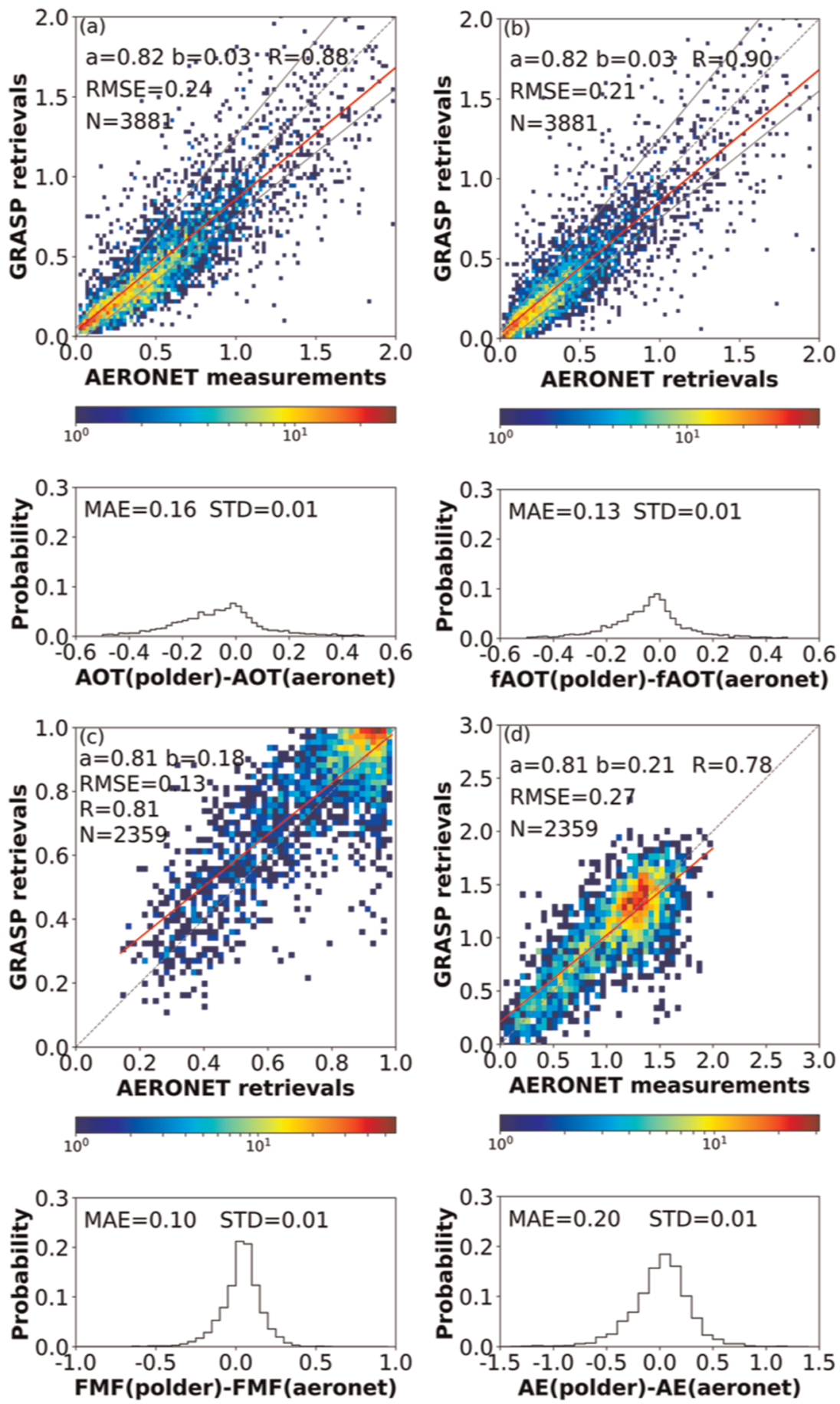

Figure 3. Intercomparison of aerosol optical properties retrieved using the POLDER/PARASOL component approach and the corresponding operational AERONET product over ESA region for 2005 to 2013: (a) AOT, (b) fAOT, (c) FMF, and (d) AE. The gray dashed lines represent the one to one line, the gray solid lines represent expected error: $Y=(1 \pm 0.20) X \pm 0.05$, and the red lines represent the fitting line.

desert, the Sichuan Basin, the Indo-China Peninsula, and South China are associated with different aerosol emission sources. In the months of JJA season, high AOTs are observed in East China and the Taklimakan desert region, where some strong anthropogenic or natural aerosol emission sources exist. High AOTs are also observed in East and Central China, North China Plain, the Sichuan Basin, and North India in the months of September, October, and November (SON season). High AOT in Indian subcontinent was 
Table 3

Statistics of Intercomparison for AOT and fAOT at $440 \mathrm{~nm}$ Between GRASP/Component Retrievals and AERONET Products at Each Site in Table 2 and Figure 2

\begin{tabular}{|c|c|c|c|c|c|c|}
\hline & AOT & fAOT & AOT & fAOT & AOT & fAOT \\
\hline Site & \multicolumn{2}{|c|}{$\operatorname{AMO}(N=13)$} & \multicolumn{2}{|c|}{$\operatorname{BEY}(N=9)$} & \multicolumn{2}{|c|}{$\operatorname{BJC}(N=36)$} \\
\hline$A$ & 0.82 & 0.49 & I & I & 0.80 & 0.85 \\
\hline$B$ & 0.07 & 0.14 & I & I & 0.06 & 0.03 \\
\hline$R$ & 0.94 & 0.98 & / & / & 0.95 & 0.96 \\
\hline$R M S E$ & 0.18 & 0.31 & I & I & 0.25 & 0.20 \\
\hline$M A E$ & 0.13 & 0.19 & I & I & 0.17 & 0.15 \\
\hline$S T D$ & 0.09 & 0.03 & I & I & 0.05 & 0.04 \\
\hline Site & \multicolumn{2}{|c|}{$\mathrm{BJI}(N=312)$} & \multicolumn{2}{|c|}{$\mathrm{CKU}(N=134)$} & \multicolumn{2}{|c|}{$\operatorname{DLZ}(N=159)$} \\
\hline$A$ & 0.74 & 0.76 & 0.65 & 0.57 & 1.01 & 0.98 \\
\hline$B$ & 0.10 & 0.07 & 0.11 & 0.07 & 0.04 & 0.01 \\
\hline$R$ & 0.87 & 0.89 & 0.81 & 0.79 & 0.66 & 0.76 \\
\hline$R M S E$ & 0.38 & 0.33 & 0.21 & 0.25 & 0.13 & 0.08 \\
\hline$M A E$ & 0.24 & 0.20 & 0.15 & 0.19 & 0.07 & 0.04 \\
\hline$S T D$ & 0.02 & 0.02 & 0.04 & 0.04 & 0.09 & 0.07 \\
\hline Site & \multicolumn{2}{|c|}{$\operatorname{EPA}(N=81)$} & \multicolumn{2}{|c|}{ FKK $(N=33)$} & \multicolumn{2}{|c|}{$\operatorname{GHC}(N=180)$} \\
\hline$A$ & 0.78 & 0.76 & 0.69 & 0.69 & 0.79 & 0.85 \\
\hline$B$ & 0.03 & 0.01 & 0.05 & 0.04 & 0.09 & 0.08 \\
\hline$R$ & 0.74 & 0.72 & 0.78 & 0.79 & 0.75 & 0.84 \\
\hline$R M S E$ & 0.23 & 0.23 & 0.15 & 0.13 & 0.23 & 0.17 \\
\hline$M A E$ & 0.17 & 0.18 & 0.11 & 0.09 & 0.18 & 0.13 \\
\hline$S T D$ & 0.08 & 0.08 & 0.10 & 0.09 & 0.05 & 0.04 \\
\hline Site & \multicolumn{2}{|c|}{$\operatorname{ISK}(N=11)$} & \multicolumn{2}{|c|}{$\operatorname{JAP}(N=224)$} & \multicolumn{2}{|c|}{$\operatorname{KAP}(N=462)$} \\
\hline$A$ & 0.92 & 1.69 & 0.85 & 0.85 & 0.98 & 0.95 \\
\hline$B$ & 0.04 & -0.06 & -0.01 & 0.01 & -0.04 & 0.03 \\
\hline$R$ & 0.75 & 0.63 & 0.80 & 0.86 & 0.80 & 0.87 \\
\hline$R M S E$ & 0.06 & 0.05 & 0.17 & 0.11 & 0.24 & 0.18 \\
\hline$M A E$ & 0.05 & 0.04 & 0.14 & 0.07 & 0.17 & 0.12 \\
\hline$S T D$ & 0.27 & 0.69 & 0.04 & 0.03 & 0.03 & 0.03 \\
\hline Site & \multicolumn{2}{|c|}{$\operatorname{LHR}(N=358)$} & \multicolumn{2}{|c|}{$\operatorname{MDH}(N=81)$} & \multicolumn{2}{|c|}{$\operatorname{OSK}(N=143)$} \\
\hline$A$ & 0.84 & 0.91 & 0.92 & 0.88 & 0.57 & 0.58 \\
\hline$B$ & -0.04 & -0.02 & 0.01 & -0.01 & 0.15 & 0.06 \\
\hline$R$ & 0.87 & 0.90 & 0.87 & 0.88 & 0.73 & 0.81 \\
\hline$R M S E$ & 0.23 & 0.16 & 0.19 & 0.18 & 0.17 & 0.15 \\
\hline$M A E$ & 0.19 & 0.11 & 0.14 & 0.14 & 0.12 & 0.11 \\
\hline$S T D$ & 0.03 & 0.02 & 0.06 & 0.05 & 0.05 & 0.04 \\
\hline Site & \multicolumn{2}{|c|}{$\operatorname{PHR}(N=120)$} & PUN $(1$ & 245) & QOM $(\Lambda$ & \\
\hline$A$ & 0.90 & 1.02 & 0.84 & 0.86 & 0.26 & 0.07 \\
\hline$B$ & 0.00 & -0.02 & -0.03 & -0.04 & 0.08 & 0.02 \\
\hline$R$ & 0.96 & 0.95 & 0.79 & 0.84 & 0.16 & 0.13 \\
\hline$R M S E$ & 0.11 & 0.10 & 0.16 & 0.14 & 0.08 & 0.05 \\
\hline$M A E$ & 0.07 & 0.06 & 0.14 & 0.11 & 0.06 & 0.03 \\
\hline$S T D$ & 0.02 & 0.03 & 0.04 & 0.04 & 0.17 & 0.06 \\
\hline Site & $\operatorname{SOL}(N$ & $=50)$ & $\mathrm{SRH}(\Lambda$ & 72) & SPU $(N$ & \\
\hline$A$ & 1.13 & 0.95 & 0.78 & 0.59 & 0.85 & 0.87 \\
\hline$B$ & -0.06 & -0.01 & 0.02 & 0.05 & 0.04 & -0.01 \\
\hline$R$ & 0.91 & 0.92 & 0.79 & 0.77 & 0.77 & 0.81 \\
\hline$R M S E$ & 0.25 & 0.19 & 0.16 & 0.14 & 0.23 & 0.21 \\
\hline$M A E$ & 0.15 & 0.13 & 0.11 & 0.10 & 0.18 & 0.17 \\
\hline$S T D$ & 0.07 & 0.06 & 0.07 & 0.06 & 0.05 & 0.05 \\
\hline Site & TPC $(N$ & $=47)$ & UBR $(I$ & :44) & USR $(N$ & \\
\hline$A$ & 0.80 & 0.85 & 0.80 & 0.81 & 1.21 & 1.20 \\
\hline$B$ & 0.05 & 0.01 & 0.06 & 0.01 & 0.03 & 0.04 \\
\hline$R$ & 0.75 & 0.80 & 0.84 & 0.84 & 0.82 & 0.78 \\
\hline$R M S E$ & 0.24 & 0.21 & 0.23 & 0.24 & 0.25 & 0.25 \\
\hline$M A E$ & 0.19 & 0.17 & 0.17 & 0.18 & 0.14 & 0.16 \\
\hline$S T D$ & 0.11 & 0.10 & 0.08 & 0.08 & 0.14 & 0.15 \\
\hline Site & $\mathrm{XIH}(N$ & $=597)$ & XIL $(N$ & 153) & All sites & $=3,881)$ \\
\hline$A$ & 0.84 & 0.81 & 0.98 & 1.04 & 0.82 & 0.82 \\
\hline
\end{tabular}

observed probably due to many anthropogenic activities including industry, combustion of biofuels (such as wood, crop residues, and dung), transport, power generation, and agricultural burning (Fan et al., 2008). It can be noted that the AOT in the Sichuan basin remains high throughout the whole year due to the combination of emissions and regional atmospheric circulation (Qian \& Giorgi, 2000). In the Tibetan Plateau, however, very low AOT (less than 0.1) is attributed to the least anthropogenic and natural aerosol emission sources.

Figure 6 shows that high values of fAOT (about 1.0) are observed over Sichuan Basin of China, Indo-China Peninsula (e.g., Burma, Laos, Vietnam, and Thailand), and South China in March and April because of many fine particles emitted from biomass burning, anthropogenic activities during this period. The greatest amount (330 Tg) of biomass burning occurs in Southeast Asia, which is mainly attributed to the slash-and-burn agriculture and timber harvesting (Streets et al., 2003). Because of the crop-residue burning, China follows with $180 \mathrm{Tg}$ per year (Streets et al., 2003), and this is the reason for the very high fAOT in the North China Plain in June. The results of our retrievals are also in line with the results of previous field experiments (e.g., Seinfeld et al., 2004; Tang et al., 2003) and satellite observations (e.g., Zhang et al., 2019). In addition, several previous studies (Zhang et al., 2008, 2012) had demonstrated that high fAOT values over Sichuan Basin of China are associated with high organic carbon concentration. Medium values of fAOT (around 0.6) in the North China Plain are observed all year long except in June, which is attributed to the industrial aerosols of megacities with high population density and pollution level (e.g., ammonium nitrate and ammonium sulfate). The study of Li et al. (2015), which is based on AERONET measurements, also found an important contribution of fine mode particles in Beijing in the period 2002-2013. Detection of fAOT with the values of about 0.2 over the Pacific Ocean region is consistent with the generation of fine mode carbonaceous particles in widespread fires in Southeast Asia during the MAM season as their transport away from the continent and toward Japan (Chameides et al., 1999; Seinfeld et al., 2004), fAOT with the values of about 0.2 are detected over the Pacific regions. Similarly, fAOT over the Indian Ocean is associated with carbonaceous particles emitted from anthropogenic and biomass burning emissions in India and South Asia (Ramanathan et al., 2001). In addition, it can be noted that a very high fAOT over Indo-China Peninsula in 2007, 2009, 2010, 2012, and 2013 may be attributed to more frequent fires and El Niño-induced droughts in this region (Marlier et al., 2012) (see Figure A5). The El Niño events were identified by the NCC/CMA (National Climate Center of China Meteorological Administration) standard during the period 2006-2007 and 2009-2010 (Ren et al., 2018).

It can be seen from Figure 7 that the highest cAOT values are observed over the Taklimakan desert in the months of MAM and JJA seasons because of the natural mineral dust emissions in this region. The dust storms in East Asia during the MAM season are mainly attributed to the combined effects of low rainfall, increased occurrence of high winds associated with cold fronts, and freshly tilled soil for spring planting (Seinfeld et al., 2004). Some coarse particles are also observed in East China because the mineral dust particles emitted from sources in East Asia can be transported aloft through boundary layer convection and vertical motions associated with frontal boundaries (Seinfeld et al., 2004). The retrievals 
Table 3

Continued

\begin{tabular}{lcccccc}
\hline & AOT & fAOT & AOT & fAOT & AOT & fAOT \\
\hline$B$ & 0.03 & 0.06 & 0.03 & 0.02 & 0.03 & 0.03 \\
$R$ & 0.90 & 0.91 & 0.91 & 0.93 & 0.88 & 0.90 \\
$R M S E$ & 0.32 & 0.30 & 0.14 & 0.12 & 0.24 & 0.21 \\
$M A E$ & 0.21 & 0.18 & 0.09 & 0.07 & 0.16 & 0.13 \\
$S T D$ & 0.02 & 0.02 & 0.04 & 0.03 & 0.01 & 0.01 \\
\hline
\end{tabular}

Note. The values of slope $(A)$, intercept $(B)$, correlation coefficient $(R)$, root-mean-square error (RMSE), mean absolute error $(M A E)$, standard error deviation $(S T D)$, and number of measurements $(N)$ are presented. indicate that most of East China (e.g., North China Plain) can be influenced significantly by the mineral dust emitted from the Taklimakan and Gobi deserts in the northwestern China and Mongolia during the MAM season, which is consistent with previous studies (Eck et al., 2005; Fan et al., 2008; Seinfeld et al., 2004; Xia et al., 2005, 2006). Figure A6 shows that dust loading (cAOT) over the Taklimakan desert exhibits significant interannual variability. That is, lower values are observed in 2005 and 2009, while higher values are observed in 2006 and 2007. This pattern is consistent with a study by Nan and Wang (2018) that also found the lowest dust extinction in 2009 over the Taklimakan desert during
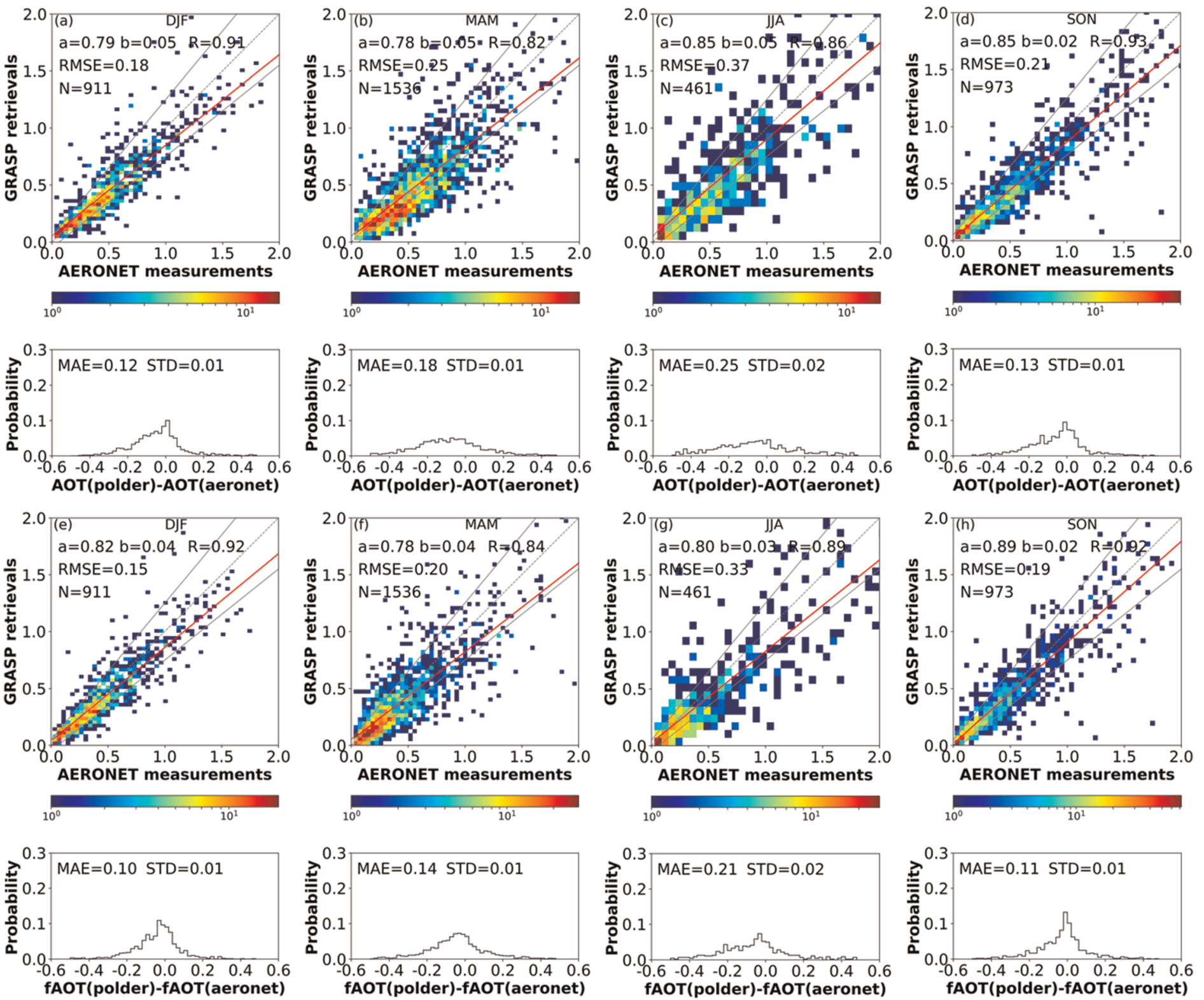

Figure 4. Intercomparison of AOT (a-d) and fAOT (e-h) retrieved using the POLDER/PARASOL component approach and the corresponding operational AERONET product over ESA region for different season: December, January, and February (DJF); March, April, and May (MAM); June, July, and August (JJA); and September, October, and November (SON). The gray dashed lines represent the one to one line, the gray solid lines represent expected error: $Y=(1 \pm 0.20) X \pm 0.05$, and the red lines represent the fitting line. 

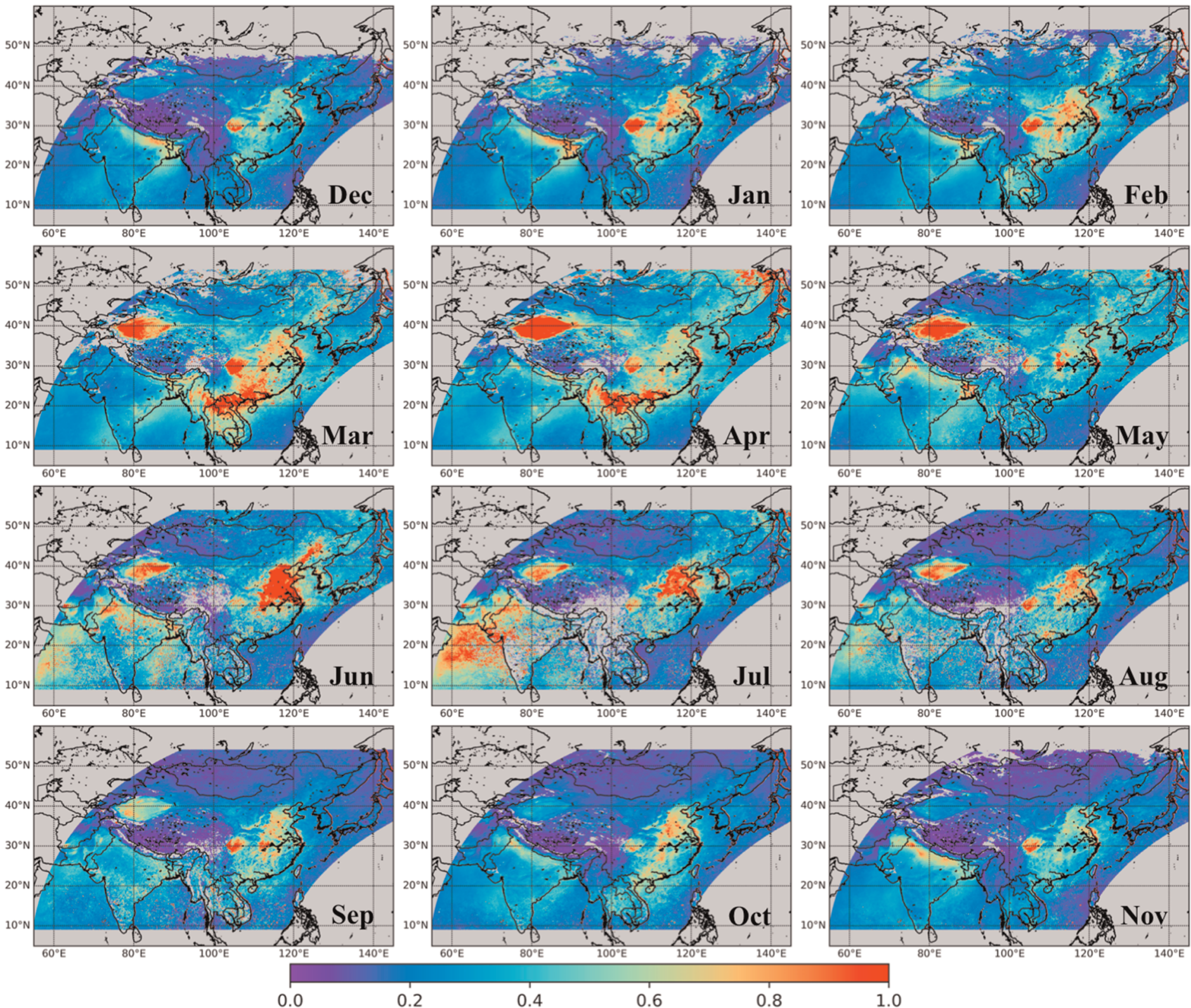

0.2

0.4

0.6

0.8

1.0

Figure 5. Monthly means of aerosol optical thickness (AOT) at $565 \mathrm{~nm}$ derived by the GRASP/Component algorithm from POLDER/PARASOL observations for the period 2005 to 2013.

2007-2016 using CALIOP and MODIS observations. This interannual variability is most likely related to variabilities in wind speed, precipitation, and atmospheric circulation that govern the dust emissions. In addition, in the months of JJA season, high cAOT values are observed in India and over the Arabian Sea, which can result from mineral dust emissions in West Asia and North Africa. For example, several major sources of dust have maximum dust activity during the JJA season, including desert areas in Syria and Iraq where a strong northwesterly "Shamal Wind" is blowing (Choobari et al., 2014). In addition, the Sistan basin, straddling the borders between Iran, Afghanistan, and Pakistan, is considered as a major dust source in southwest Asia and belonging to the desert dust belt with attributed strong persistent northeasterly winds (Choobari et al., 2013; Ginoux et al., 2012; Kaskaoutis et al., 2015; Middleton, 1986a; Middleton, 1986b; Rashki et al., 2015). The lowest values of cAOT (lower than 0.1) are obtained from October to January over ESA when the dust emissions are very weak. 

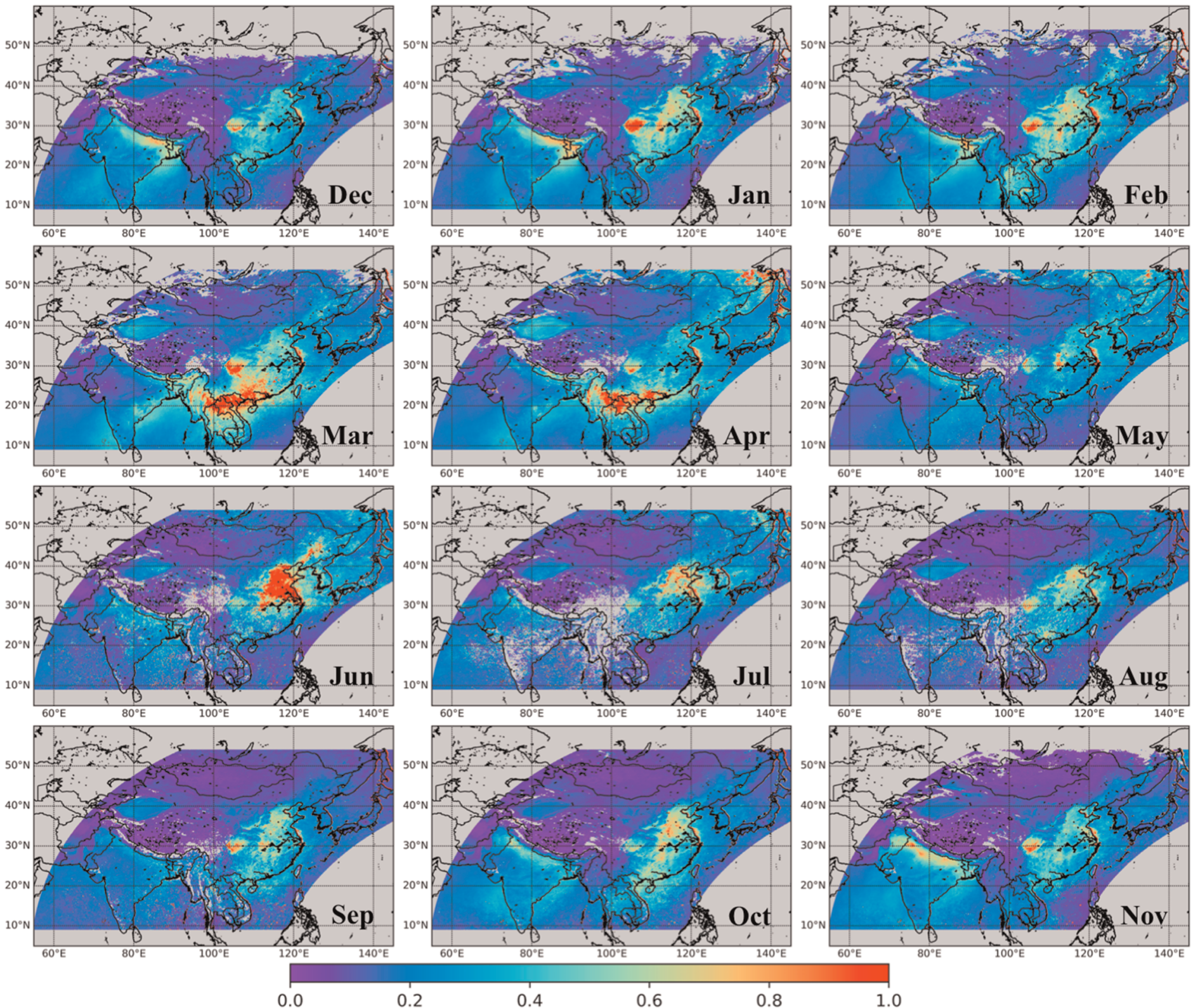

0.2

0.4

0.6

0.8

1.0

Figure 6. Monthly means of fine-mode aerosol optical thickness (fAOT) at $565 \mathrm{~nm}$ derived by the GRASP/Component algorithm from POLDER/PARASOL observations for the period 2005 to 2013.

\subsection{Monthly Variations of FMF}

The map of the derived FMF (Figure 8) presents a clear general gradient of decreasing values toward the arid and desert regions that logically reflects increasing influence of coarse mode dominating desert dust aerosol. It can be seen that the FMF values in Central and East China are varying between 0.4 and 0.8 in different months, which can be classified as a mixture of fine and coarse mode aerosols. The FMF values in South China are usually larger than 0.8, indicating dominance of fine mode aerosol particles (Lee et al., 2010), in particular for the months of DJF and SON. The FMF values over India have a typical cycle reaching the peaks in the months of November, December, and January, then decreasing in March from northwest to southeast, reaching the smallest values in JJA. In addition, the FMF values in the Tibetan Plateau region are mostly below 0.3 all year long, which indicates that coarse mode particles (mineral dust) dominate in the aerosol type. However, it should be noted that when the AOT is very low, the meaning of relative values, as of FMF for instance, is less significant. Moreover, when the aerosol loading is low, the accuracy of the 

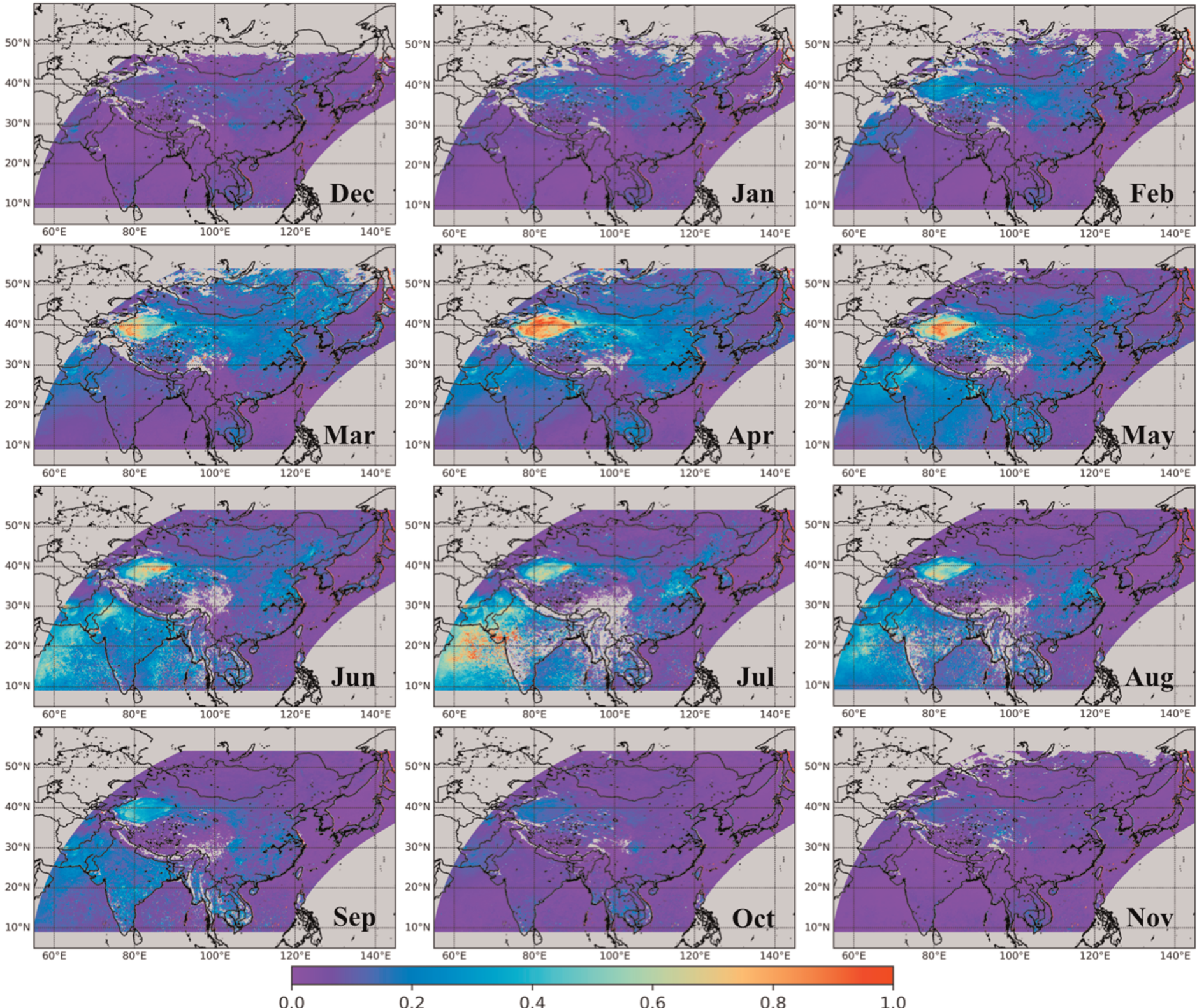

0.4

0.6

0.8

1.0

Figure 7. Monthly means of coarse mode aerosol optical thickness (cAOT) at $565 \mathrm{~nm}$ derived by the GRASP/Component algorithm from POLDER/PARASOL observations for the period 2005 to 2013.

retrievals can be affected ( $\mathrm{Li}$ et al., 2019). For example, the Tibetan Plateau is generally characterized by low aerosol concentrations; therefore, the FMF retrievals in Tibetan Plateau region may have a larger uncertainty. Similarly, the FMF over ocean should be interpreted with caution. First, because the absolute values of AOT are very low, thus, the relative values of FMF can be noisier. Second, because the number of available cloud-free pixels over ocean is significantly smaller than over land (Li et al., 2019), thus, a considerable difference in the calculated averaged values can be produced, and artifacts appear on the land-ocean boundary in the spatial patterns. Nevertheless, the continuity of land-ocean boundary is generally logical in Figure 8. One could also expect somewhat lower FMF over ocean due to the contribution of large sea salt aerosol. Although in some months and regions the calculated FMF over ocean decreases up to about 0.5 , the FMF over ocean in Figure 8 is mostly close to one. The calculated FMF therefore presents a dynamic, and we believe it reflects real physical reasons. This result suggests that the fine mode aerosol of anthropogenic origin can dominate quite often in this region even over ocean. 

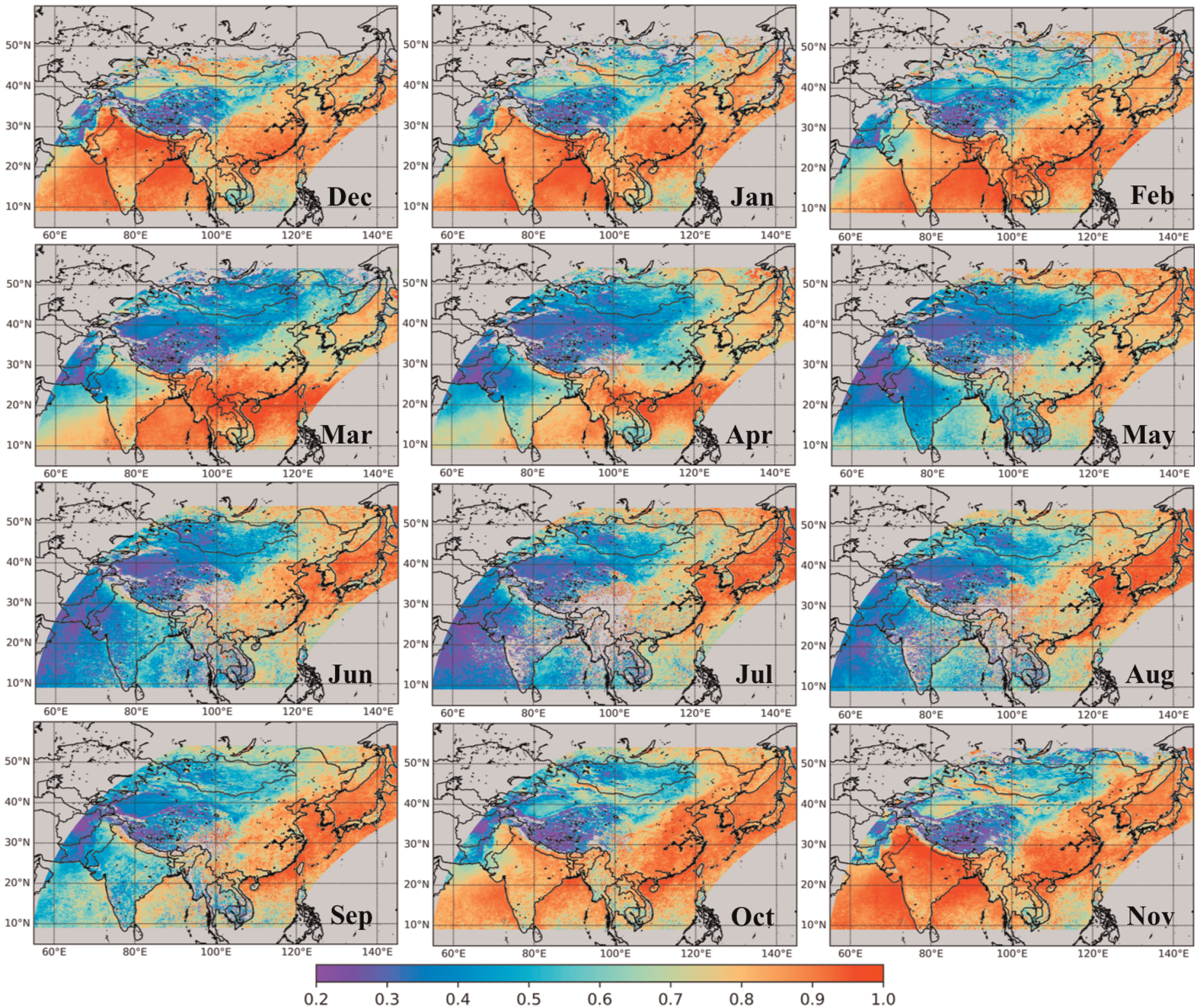

Figure 8. Monthly means of fine mode fraction (FMF) of aerosol optical thickness at $565 \mathrm{~nm}$ derived by the GRASP/Component algorithm from POLDER/ PARASOL observations for the period 2005 to 2013.

Figure 9 focuses on monthly averaged AOT, fAOT, and FMF in some regions of interest (e.g., ICP, NCP, NEI, and NWC in Figure 2). We can see that FMF in ICP region (Figure 9a) has a peak with the value of nearly 1.0 in March because of the strongest open fire events, including forest burning, savanna/grassland burning, and agricultural burning, known for this region (Uno et al., 2003). Then, the FMF decreases significantly and reaches the minimum (about 0.6) in May. It can be seen in Figure 9b that FMF in NCP region varies from 0.6 in April to 0.9 in October. During the MAM season, FMFs in NCP region can be influenced significantly by fine particles generated from anthropogenic activity (industry, combustion of biofuels, transport, etc.) and also can be affected by the coarse particles (mineral dust) emitted from the desert regions in the Northwestern China (Eck et al., 2005; Fan et al., 2008; Seinfeld et al., 2004; Xia et al., 2005, 2006). Note that FMF has a peak (larger than 0.8 ) in June as the strong agricultural waste burning occurs in the NCP region and south of NCP (Cao et al., 2006). In addition, the lower FMF in eastern China during July and August, as compared to that in October and November, could be attributed to the hygroscopic growth of the soluble 

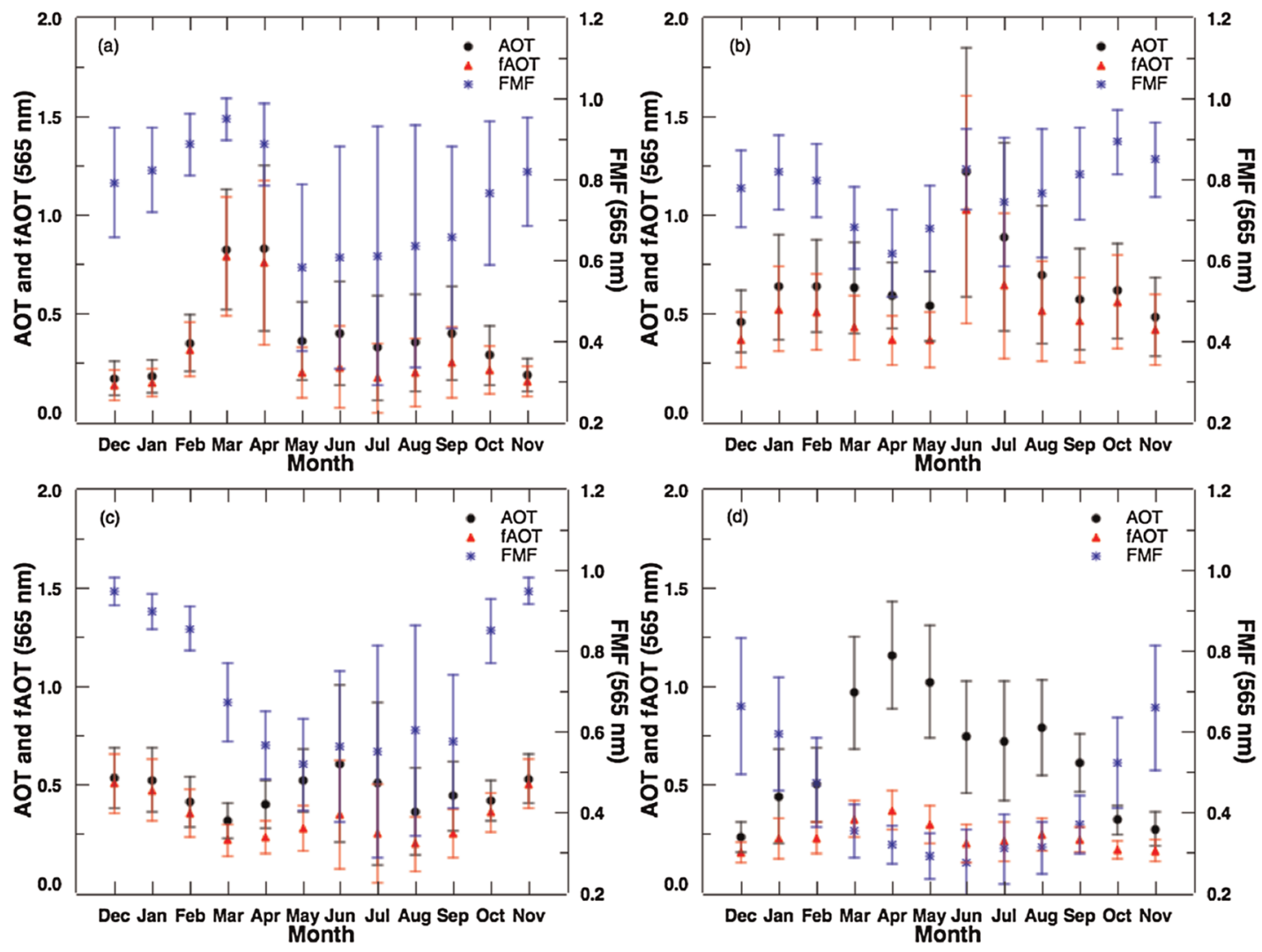

Dec Jan Feb Mar Apr May Jun Jul Aug Sep Oct Nov

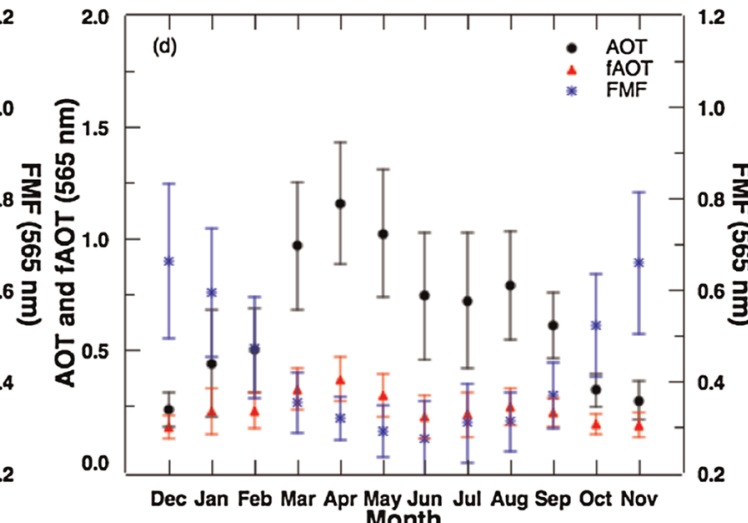

Figure 9. Monthly means of AOT, fAOT, and FMF at $565 \mathrm{~nm}$ for some regions of interest: (a) ICP, (b) NCP, (c) NEI, and (d) NWC.

inorganic particles and elevated relative humidity in summer. The regional mean of FMF over NCP (Figure 9b) in July and August is about 0.75, which is similar to value of 0.72 obtained by Wei et al. (2020) in August. The FMF in NEI region (Figure 9c) reaches the maximum (above 0.9) in November and December, while decreases to the minimum (about 0.5) in May, June, and July. The results also show that aerosols over India are impacted by the coarse mode particles (mineral dust) emitted from North Africa, Middle Asia, and the Sistan region, considered as major dust emission sources for aerosols in southwest Asia during the JJA season (Ginoux et al., 2012; Middleton, 1986a). At the same time, concentrations of the fine particles generated from biomass burning are very low during the JJA season. The FMF in the NWC region (Figure 9d), which represents the Taklimakan and Gobi deserts, has the lowest value (below 0.3) in May and June, indicating dominance of coarse mode aerosol particles. The FMF then reaches the maximum in November and December when the dust emission is weak, which is in agreement with the study of Lee et al. (2010).

\section{Conclusions}

The GRASP/Component version of the GRASP algorithm was applied to POLDER/PARASOL over the ESA region aiming climatological analysis of fine and coarse mode AOT and fine mode aerosol fraction. The component retrieval approach was used because it is expected to improve separating characterization of fine and coarse size modes and optimizing retrieval stability (Li et al., 2019). This is in addition to the original goal of this development-retrieval of aerosol component fractions. The sensitivity tests demonstrated that the uncertainties for AOT, fAOT, and FMF are within 1\%, 3\%, and 3\%, respectively. In addition, there is a good agreement between the GRASP/Component retrievals and the AERONET products for AOT, fAOT ( $R$ of $\sim 0.9$ ), and Ångström exponent ( $R$ of $\sim 0.8$ ) over ESA region, as well as a good correlation coefficient for FMF ( $R$ of $\sim 0.8)$.

The climatology of temporal and spatial distributions of fAOT, cAOT, AOT, and FMF over the ESA, was shown for the years 2005-2013. It reveals, for example, a peak of the FMF in Northeastern India region in 
November-December, while a minimum is from May to July. In the North China Plain region, the FMF varies from 0.6 to 0.9, showing influence of different aerosol types. The FMF below 0.3 in the Northwestern China region indicated the coarse particles desert emissions (mineral dust). We also found that FMF in the Indo-China Peninsula region has a peak of nearly 1.0 in March. In addition, the FMF value of about 0.3 and below was found for all year long in Tibetan Plateau region; however, significance of these values is limited due to generally very low aerosol loading in this region.

Overall, the presented work demonstrates potential of the GRASP/Component algorithm for studying optical properties of anthropogenic aerosols using multiangular and polarized measurements. The approach can also be applied to other remote sensing observations, such as the Directional Polarimetric Camera (DPC) launched onboard the GaoFen-5 Satellite (Dubovik et al., 2019; Li et al., 2019, 2018; Zhang et al., 2020). The derived temporal and spatial distributions of aerosol characteristics can be useful for studying environmental and climatic impacts of anthropogenic aerosol in the ESA region. Finally, the presented satellite-derived fine and coarse AOT and FMF are of importance for constraining the aerosol estimations in the global or regional aerosol models.

\section{Appendix A: Multiyear Seasonal AOT, fAOT, and cAOT}

The interannual variabilities of AOT, fAOT and cAOT for each season over the East and South Asia (Figure A1 to A12) are presented in Appendix A.


Figure A1. Averaged values for DJF season of aerosol optical thickness (AOT) at $565 \mathrm{~nm}$ derived by the GRASP/component algorithm from POLDER/PARASOL observations from 2005 to 2013. 

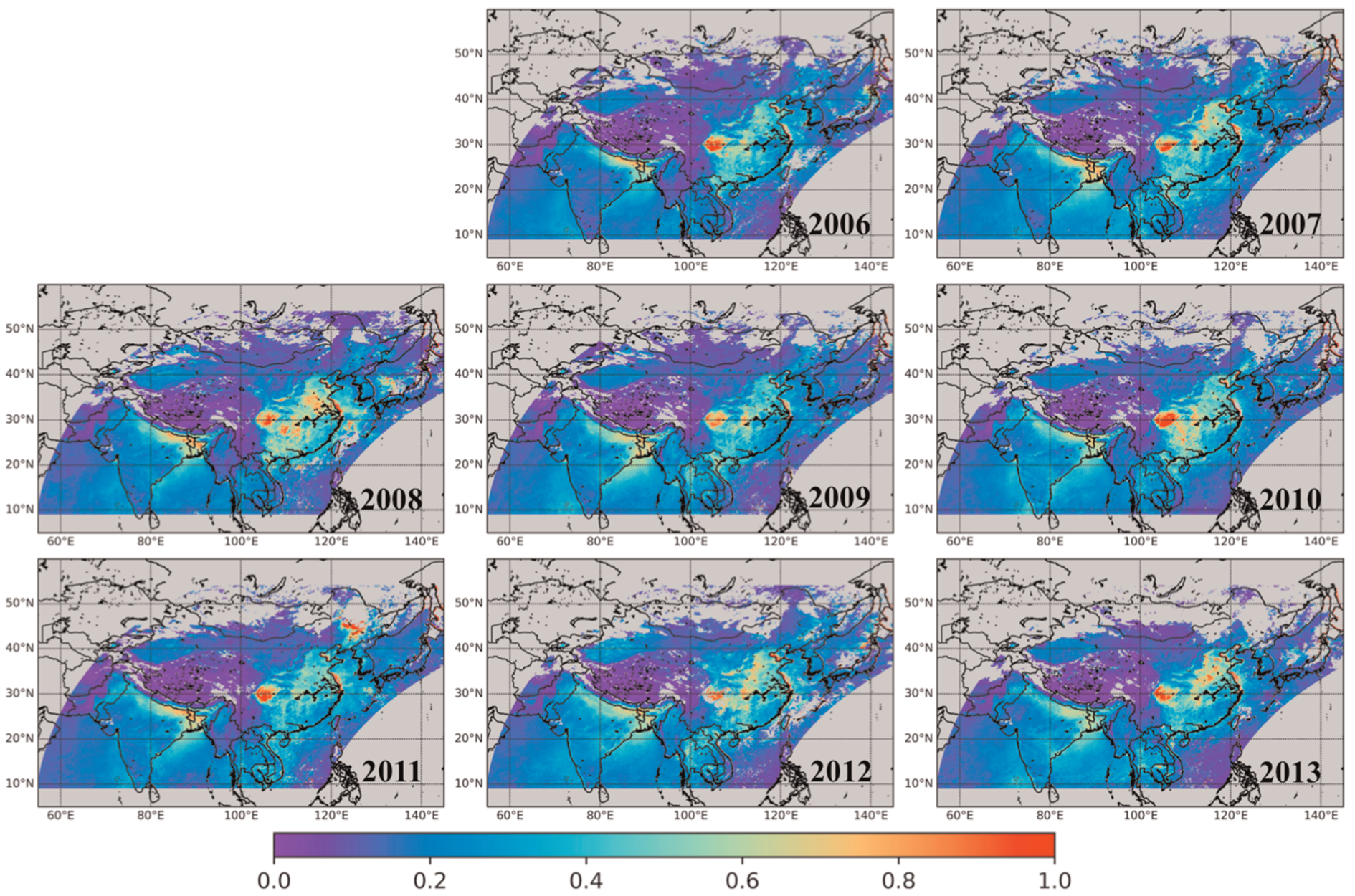

Figure A2. Averaged values for DJF season of fine mode aerosol optical thickness (fAOT) at $565 \mathrm{~nm}$ derived by the GRASP/component algorithm from POLDER/ PARASOL observations from 2005 to 2013 


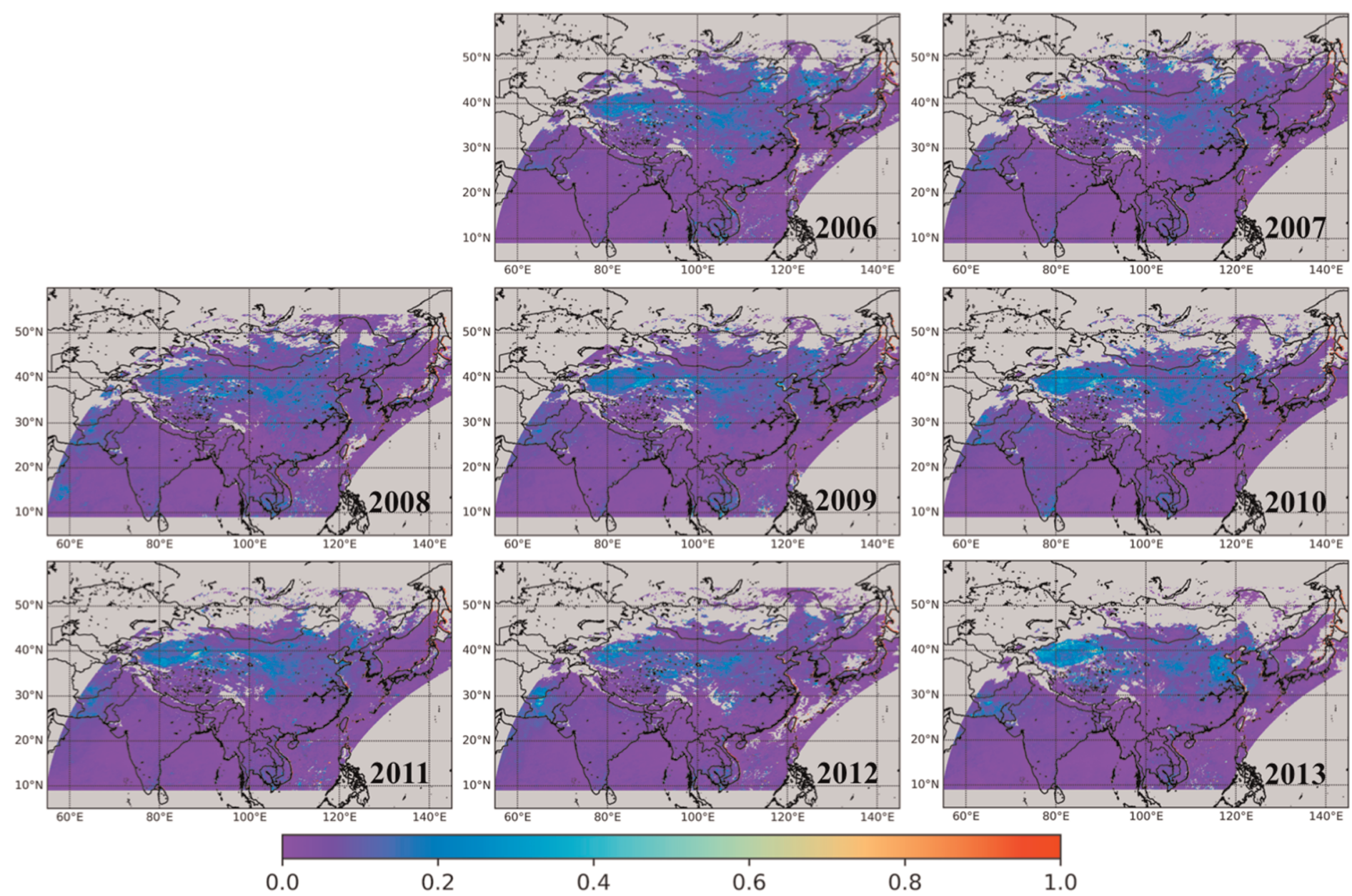

Figure A3. Averaged values for DJF season of coarse mode aerosol optical thickness (cAOT) at $565 \mathrm{~nm}$ derived by the GRASP/component algorithm from POLDER/PARASOL observations from 2005 to 2013. 

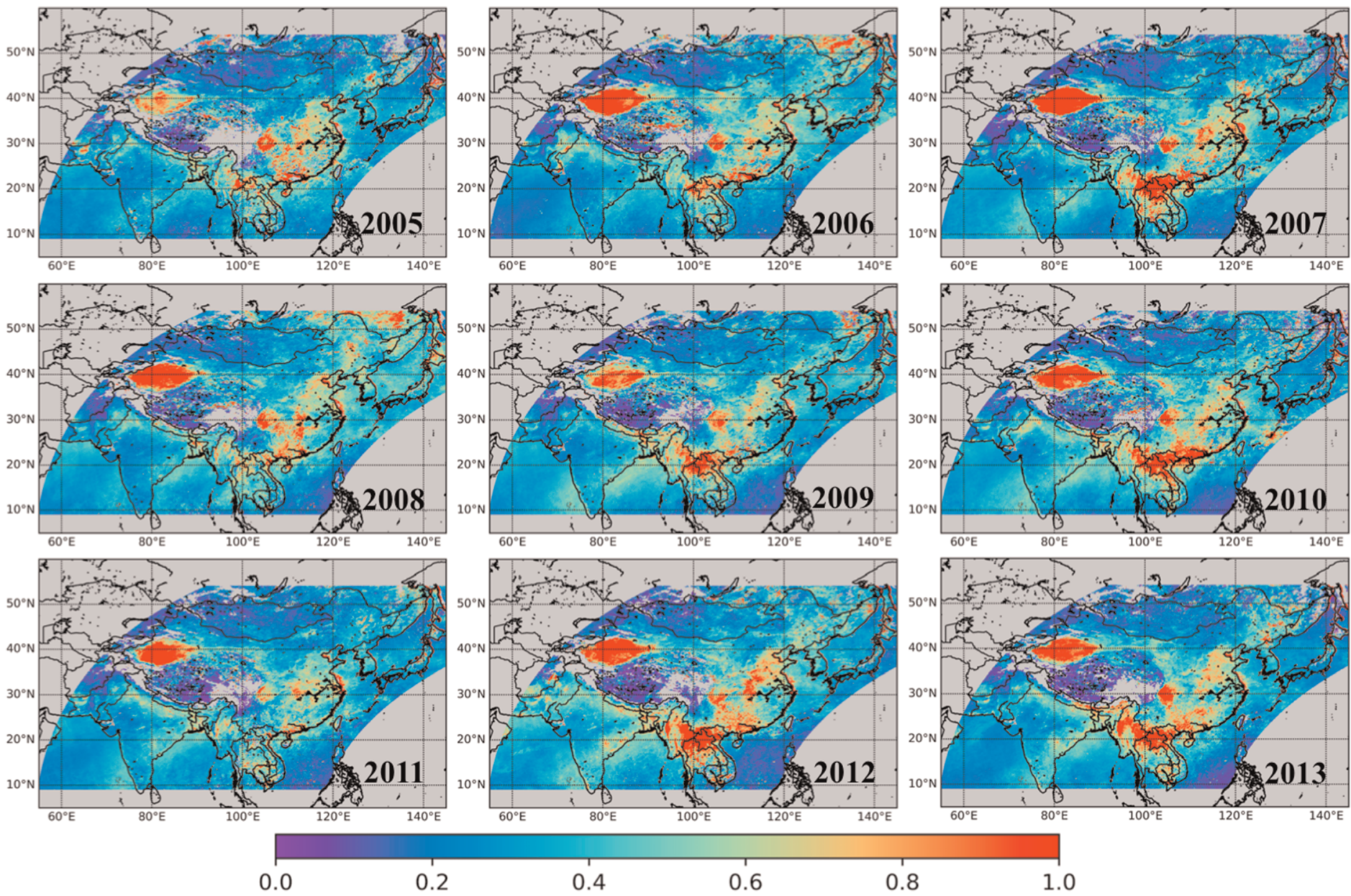

Figure A4. Same as Figure A1 but for MAM season. 

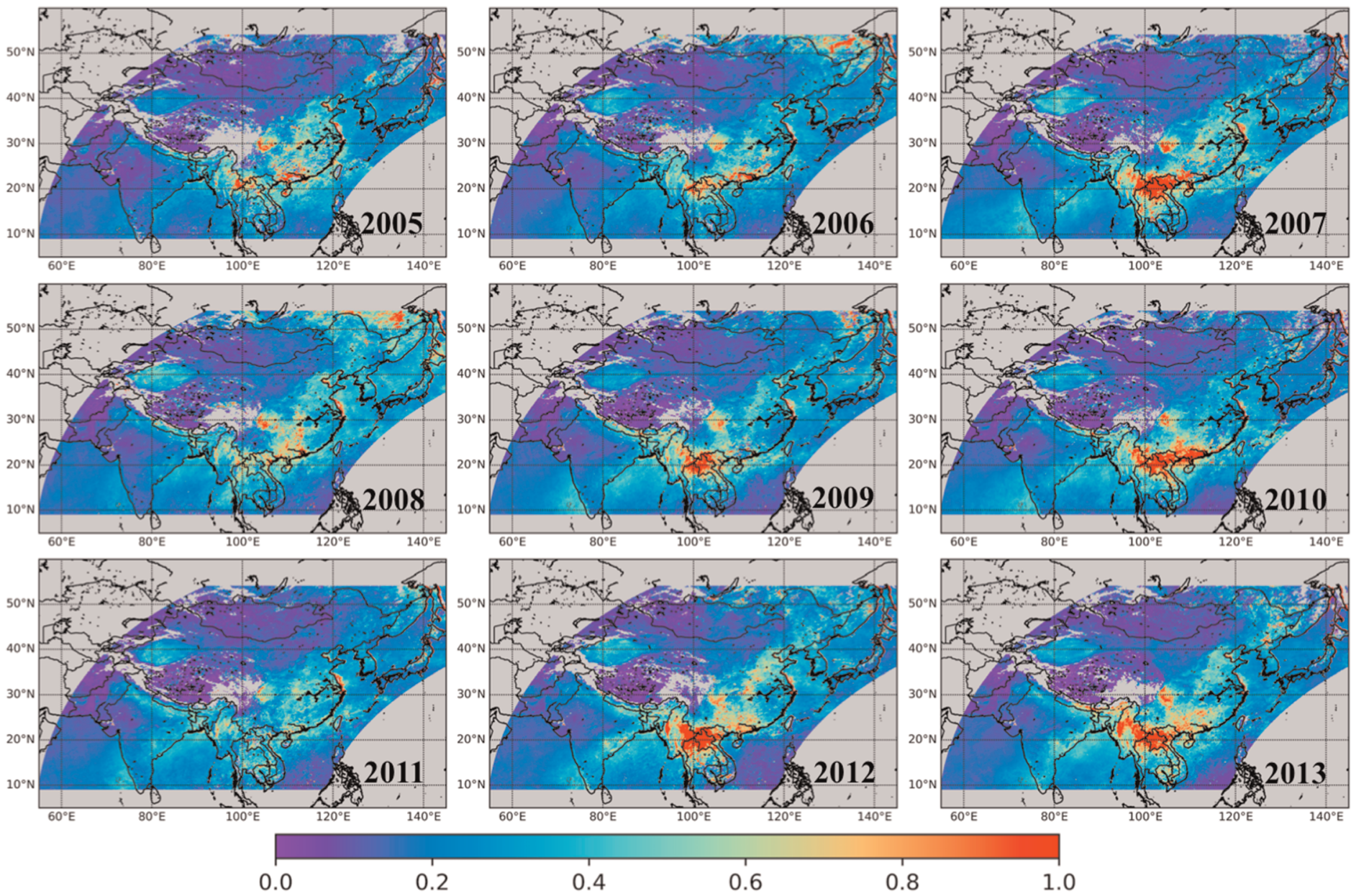

Figure A5. Same as Figure A2 but for MAM season. 

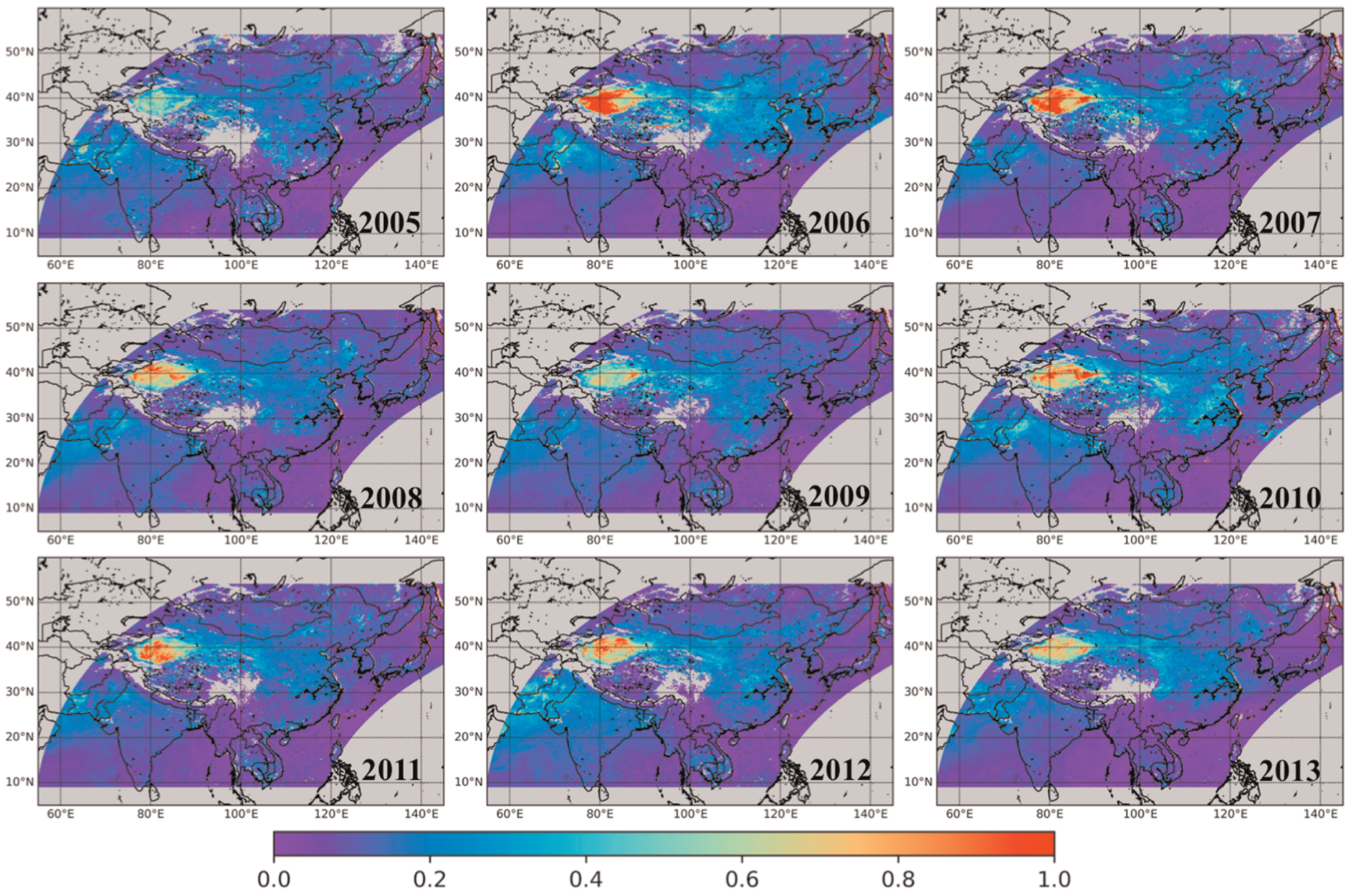

Figure A6. Same as Figure A3 but for MAM season 

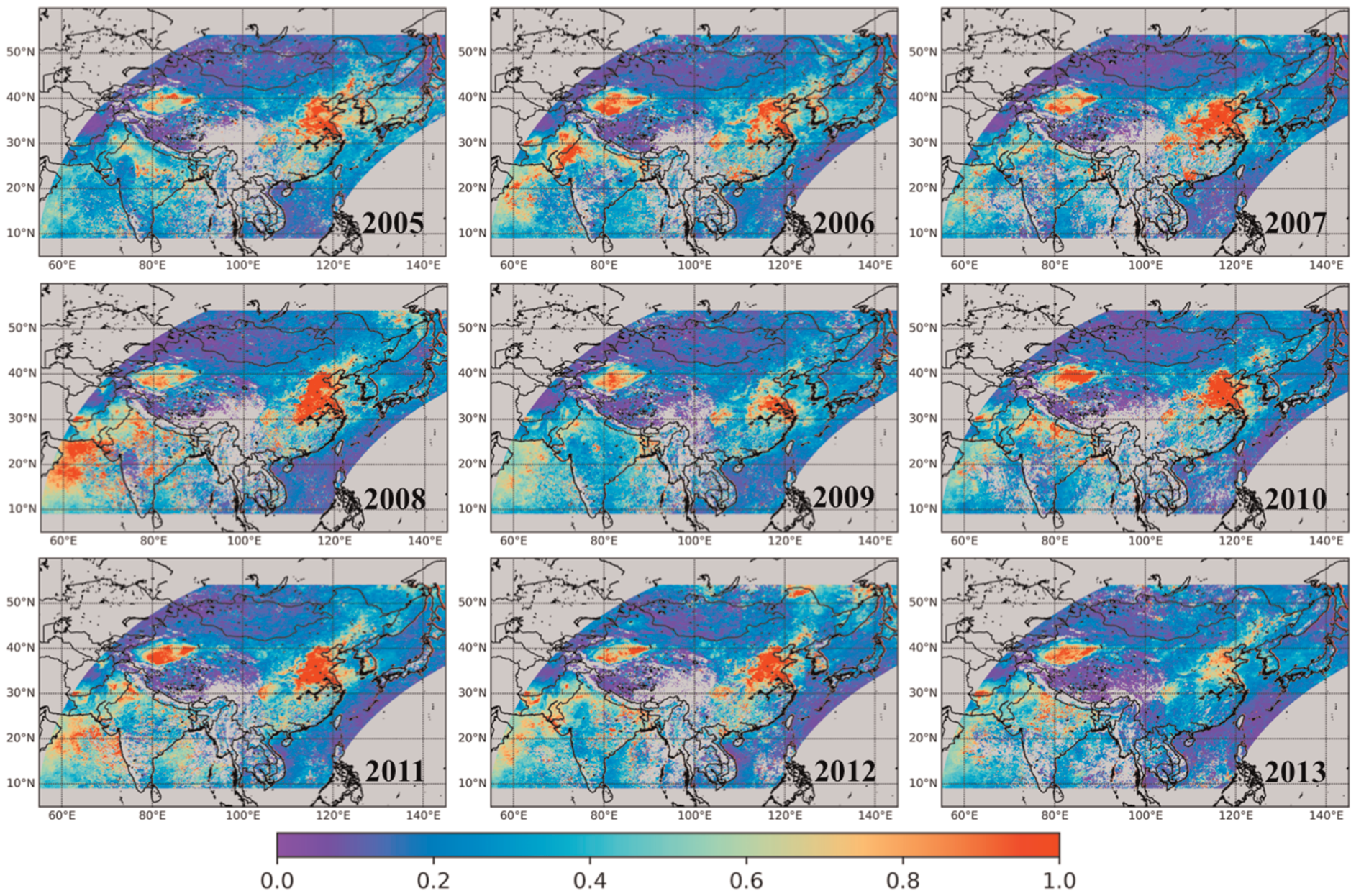

Figure A7. Same as Figure A1 but for JJA season. 

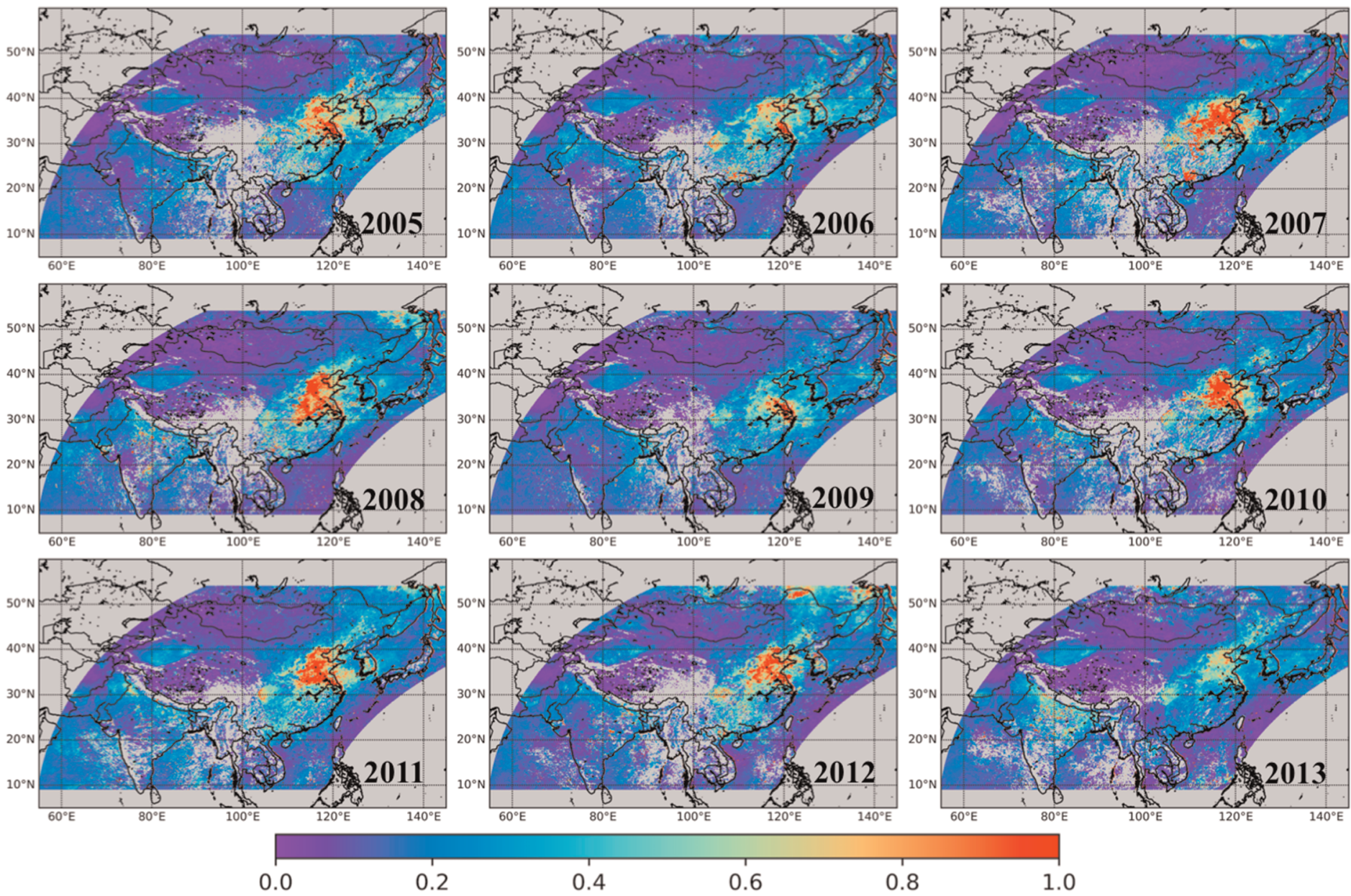

Figure A8. Same as Figure A2 but for JJA season. 

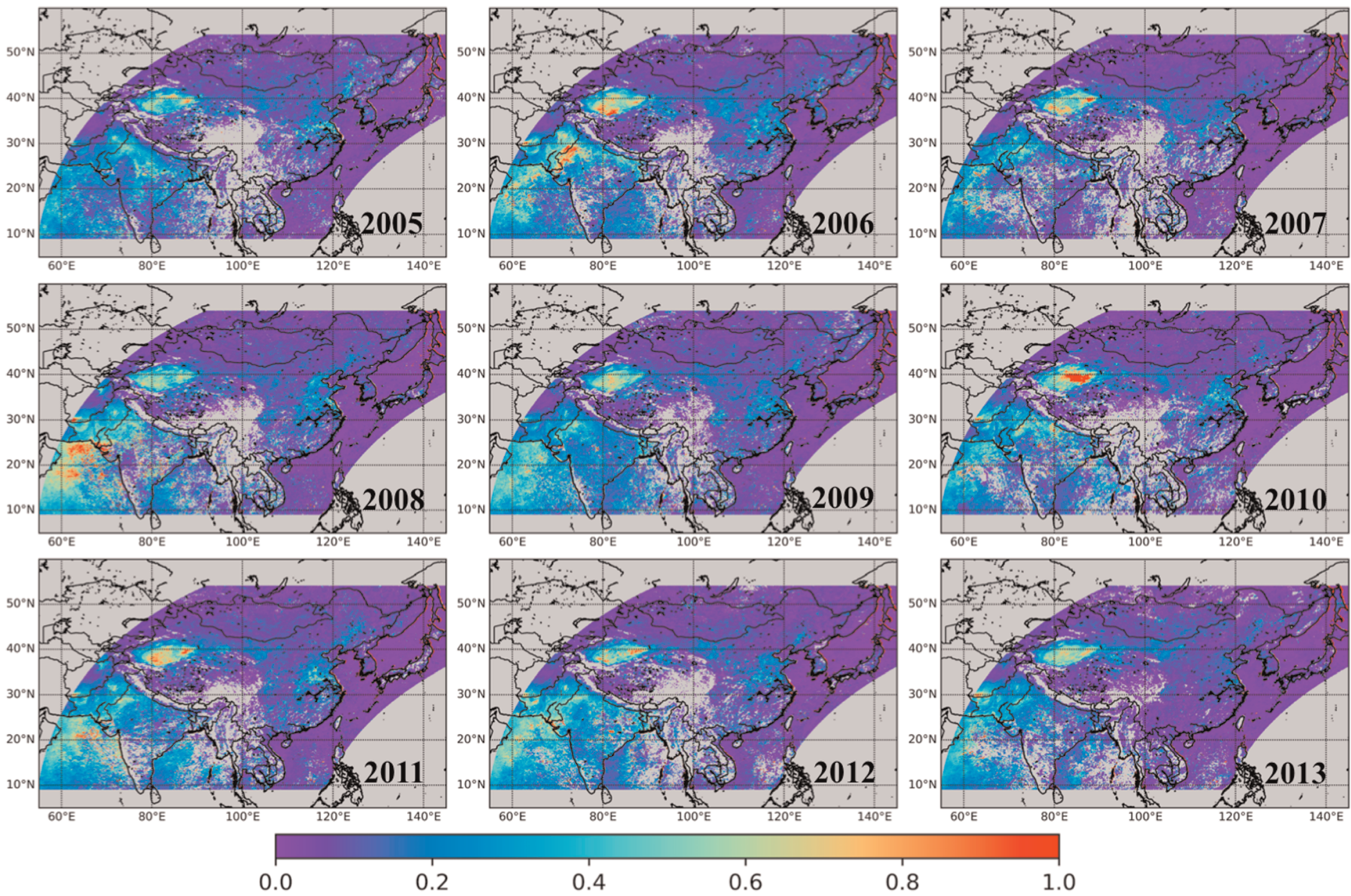

Figure A9. Same as Figure A3 but for JJA season. 

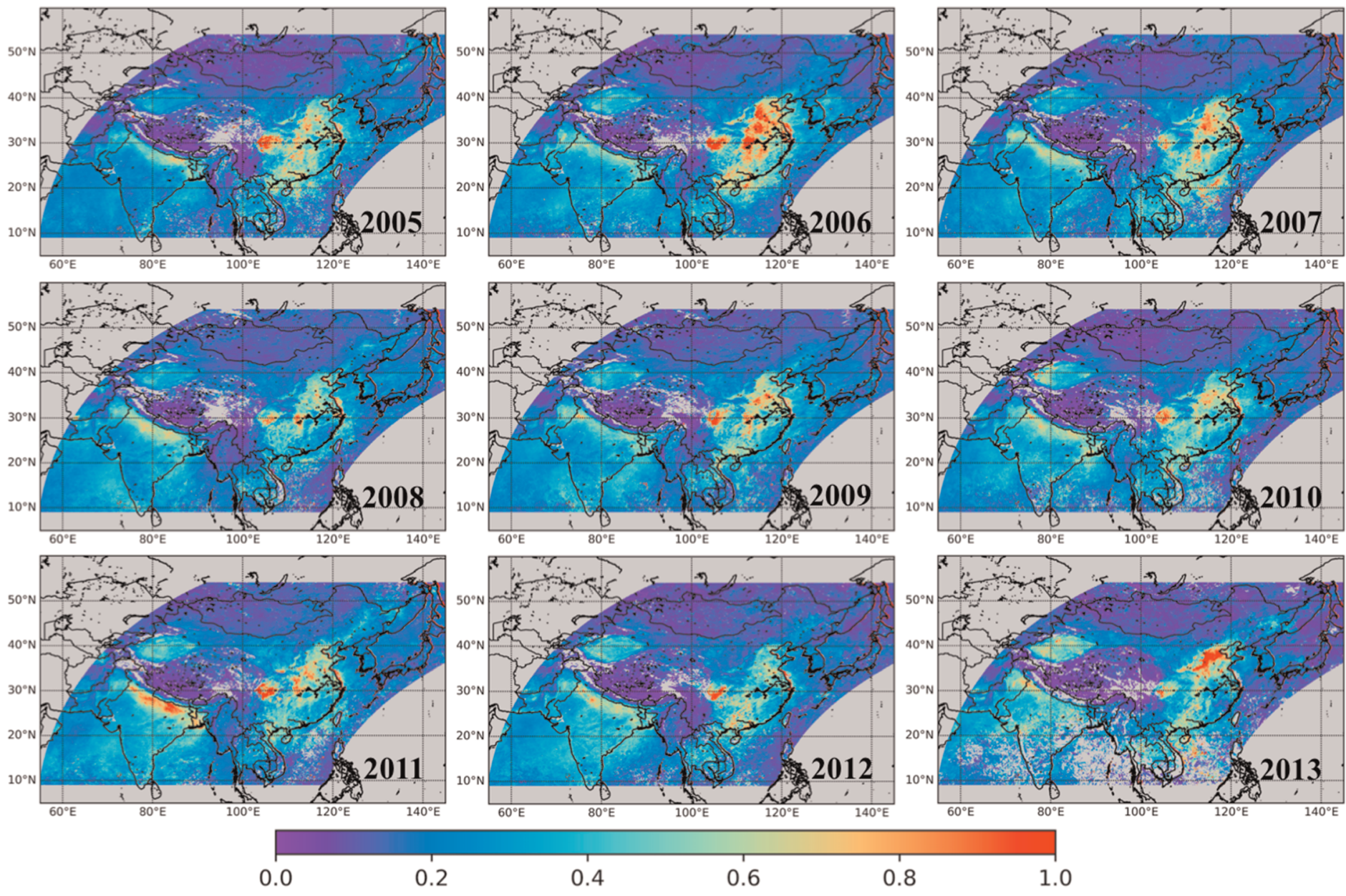

Figure A10. Same as Figure A1 but for SON season. 

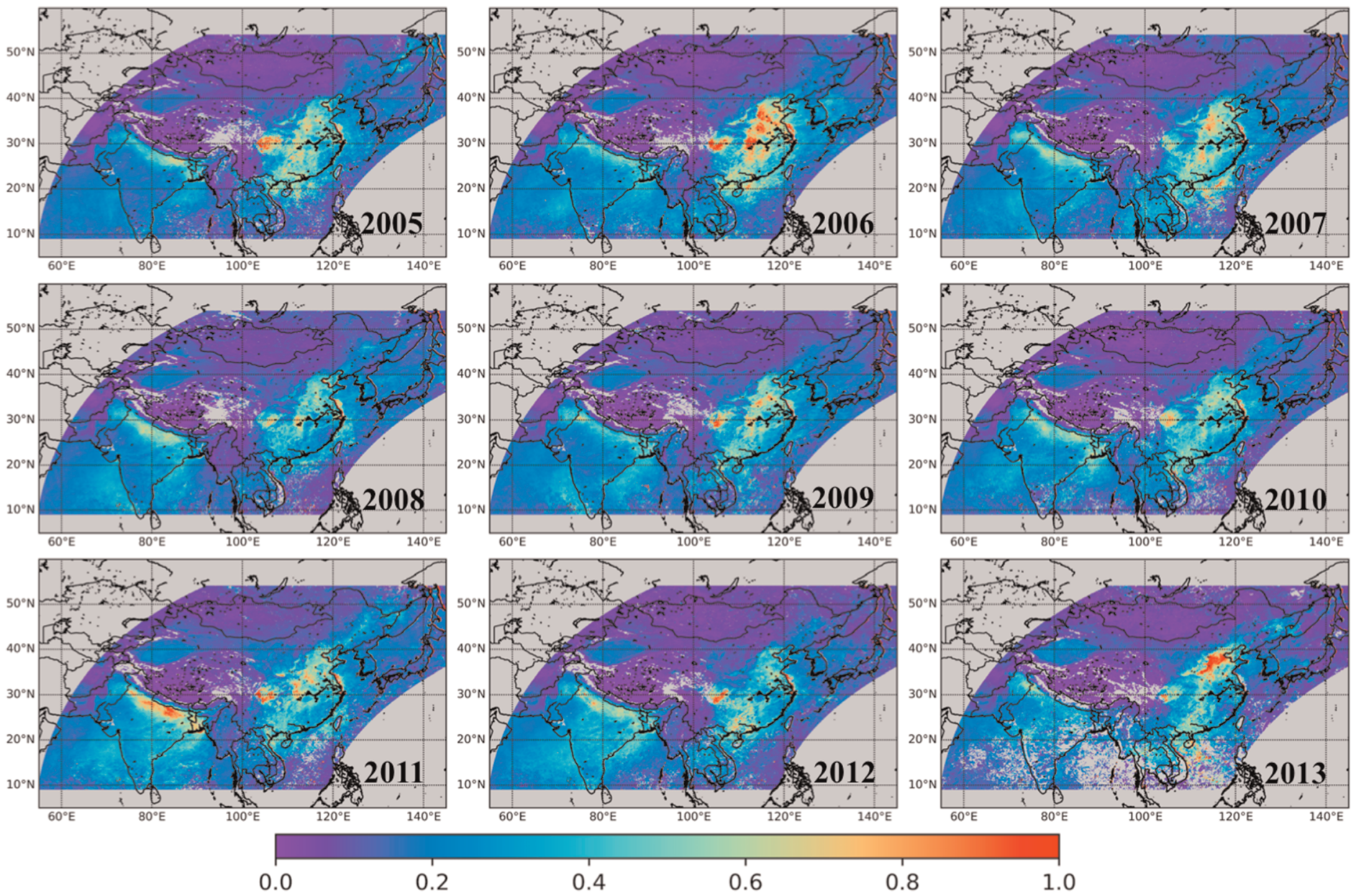

Figure A11. Same as Figure A2 but for SON season. 

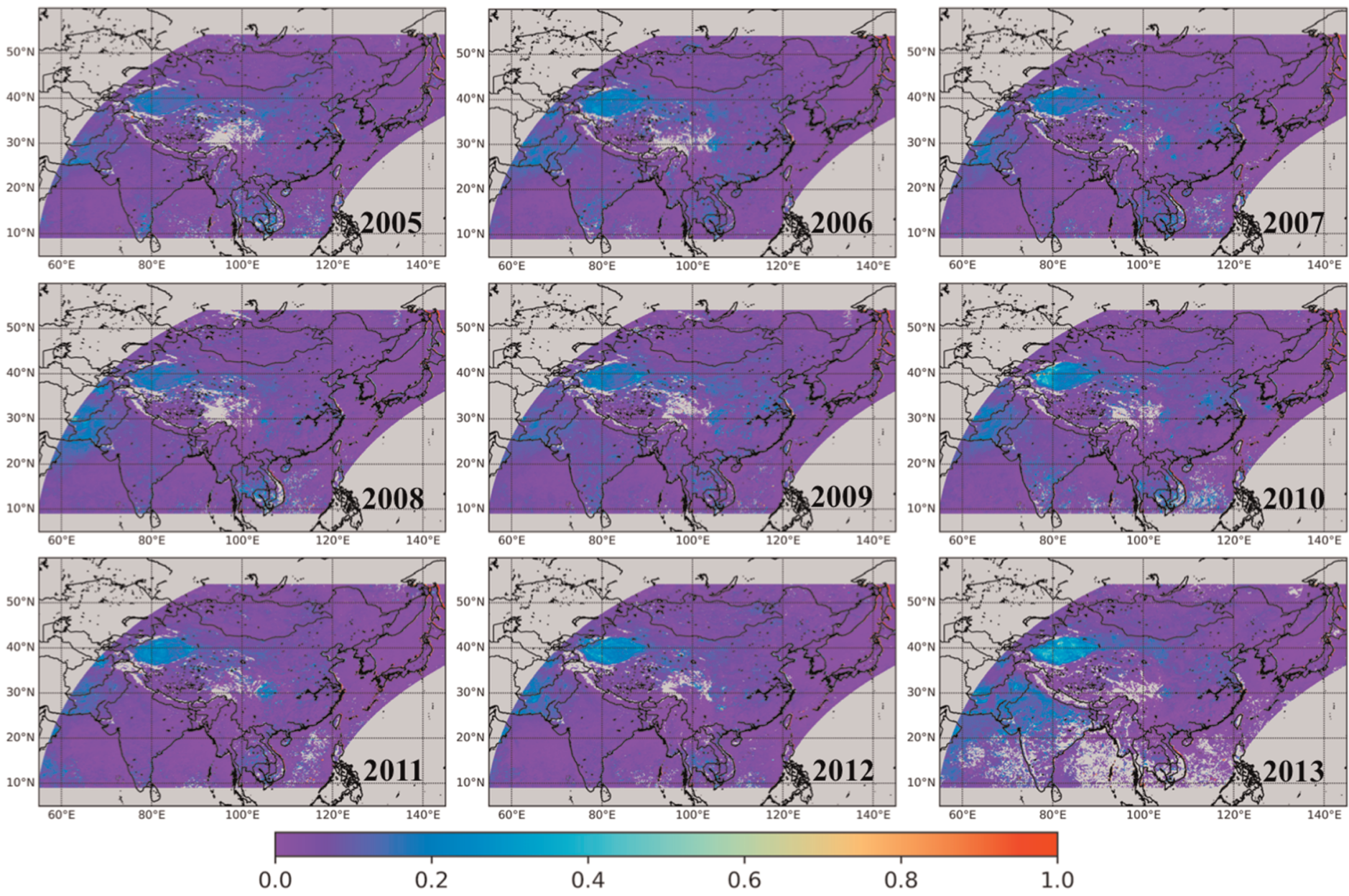

Figure A12. Same as Figure A3 but for SON season. 


\section{Data Availability Statement}

Data are available online (at https://aeronet.gsfc.nasa.gov/new_web/index.html).

\section{Acknowledgments}

This work is supported by a grant from National Natural Science Foundation of China (41825011 and 41905117) and National Key R\&D Program of China (2016YFA0601901). The component algorithm was developed as part of the Labex CaPPA project, which is funded by the French National Research Agency under Contract "ANR-11LABX-0005-01.” The authors acknowledge the entire GRASP team for the algorithm development (https://www. grasp-open.com/). The authors also thank CNES and ICARE data distribution center for providing POLDER/PARASOL data (http://www. icare.univ-lille1.fr/archive) and the principal investigators of the AERONET sites used in this study, as well as the entire AERONET team for their long-term efforts to maintain AERONET observation.

\section{References}

Arola, A., Eck, T. F., Kokkola, H., Pitkänen, M. R. A., \& Romakkaniemi, S. (2017). Assessment of cloud-related fine-mode AOD enhancements based on AERONET SDA product. Atmospheric Chemistry and Physics, 17(9), 5991-6001. https://doi.org/10.5194/acp-175991-2017

Beelen, R., Raaschou-Nielsen, O., Stafoggia, M., Andersen, Z. J., Weinmayr, G., Hoffmann, B., et al. (2014). Effects of long-term exposure to air pollution on natural-cause mortality: An analysis of 22 European cohorts within the multicentre ESCAPE project. The Lancet, 383(9919), 785-795. https://doi.org/10.1016/S0140-6736(13)62158-3

Bellouin, N., Boucher, O., Haywood, J., \& Reddy, M. S. (2005). Global estimate of aerosol direct radiative forcing from satellite measurements. Nature, 438(7071), 1138-1141. https://doi.org/10.1038/nature04348

Buriez, J. C., Vanbauce, C., Parol, F., Goloub, P., Herman, M., Bonnel, B., \& Fouquart, Y. (1997). Cloud detection and derivation of cloud properties from POLDER. International Journal of Remote Sensing, 18(13), 2785-2813. https://doi.org/10.1080/ 014311697217332

Cao, G., Zhang, X., \& Zheng, F. (2006). Inventory of black carbon and organic carbon emissions from China. Atmospheric Environment, 40(34), 6516-6527. https://doi.org/10.1016/j/atmosenv.2006.05.070

Chameides, W. L., Yu, H., Liu, S. C., Bergin, M., Zhou, X., Mearns, L., et al. (1999). Case study of the effects of atmospheric aerosols and regional haze on agriculture: An opportunity to enhance crop yields in China through emission controls? PNAS, 96(24), $13626-13633$. https://doi.org/10.1073/pnas.96.24.13626

Charlson, R. J., Schwartz, S. E., Hales, J. M., Cess, R. D., Coakley, J. A., Hansen, J. E., \& Hofmann, D. J. (1992). Climate forcing by anthropogenic aerosols. Science, 255(5043), 423-430. https://doi.org/10.1126/science.255.5043.423

Cheng, T., Gu, X., Xie, D., Li, Z., Yu, T., \& Chen, H. (2012). Aerosol optical depth and fine-mode fraction retrieval over East Asia using multi-angular total and polarized remote sensing. Atmospheric Measurement Techniques, 5(3), 501-516. https://doi.org/10.5194/amt-5501-2012

Cheng, T., Gu, X., Xie, D., Li, Z., Yu, T., \& Chen, X. (2011). Simultaneous retrieval of aerosol optical properties over the Pearl River Delta, China using multi-angular, multi-spectral, and polarized measurements. Remote Sensing of Environment, 115(7), 1643-1652. https://doi. org/10.1016/j.rse.2011.02.020

Choobari, O. A., Zawar-Reza, P., \& Sturman, A. (2013). Low level jet intensification by mineral dust aerosols. Annales Geophysicae, 31(4), 625-632. https://doi.org/10.5194/angeo-31-625-2013

Choobari, O. A., Zawar-Reza, P., \& Sturman, A. (2014). The global distribution of mineral dust and its impacts on the climate system: A review. Atmospheric Research, 138, 152-165. https://doi.org/10.1016/j.atmosres.2013.11.007

Chowdhary, J., Cairns, B., Mishchenko, M. I., Hobbs, P. V., Cota, G. F., Redemann, J., et al. (2005). Retrieval of aerosol scattering and absorption properties from photopolarimetric observations over the ocean during the CLAMS experiment. Journal of the Atmospheric Sciences, 62(4), 1093-1117. https://doi.org/10.1175/JAS3389.1

Deuzé, J. L., Bréon, F. M., Deschamps, P. Y., Devaux, C., Herman, M., Podaire, A., \& Roujean, J. L. (1993). Analysis of the POLDER (POLarization and directionality of Earth's reflectances) airborne instrument observations over land surfaces. Remote Sensing of Environment, 45(2), 137-154. https://doi.org/10.1016/0034-4257(93)90038-Y

Deuzé, J. L., Bréon, F. M., Devaux, C., Goloub, P., Herman, M., Lafrance, B., et al. (2001). Remote sensing of aerosols over land surfaces from POLDER-ADEOS-1 polarized measurements. Journal of Geophysical Research Atmospheres, 106(D5), 4913-4926. https://doi.org/ 10.1029/2000JD900364

Diner, D. J., Martonchik, J. V., Kahn, R. A., Pinty, B., Gobron, N., Nelson, D. L., \& Holben, B. N. (2005). Using angular and spectral shape similarity constraints to improve MISR aerosol and surface retrievals over land. Remote Sensing of Environment, 94(2), 155-171. https:// doi.org/10.1016/j.rse.2004.09.009

Dubovik, O., Herman, M., Holdak, A., Lapyonok, T., Tanré, D., Deuzé, J. L., et al. (2011). Statistically optimized inversion algorithm for enhanced retrieval of aerosol properties from spectral multi-angle polarimetric satellite observations. Atmospheric Measurement Techniques, 4(5), 975-1018. https://doi.org/10.5194/amt-4-975-2011

Dubovik, O., Holben, B. N., Lapyonok, T., Sinyuk, A., Mishchenko, M. I., Yang, P., \& Slutsker, I. (2002). Non-spherical aerosol retrieval method employing light scattering by spheroids. Geophysical Research Letters, 29(10), 54-1-54-4. https://doi.org/10.1029/ $2001 \mathrm{GL} 014506$

Dubovik, O., \& King, M. D. (2000). A flexible inversion algorithm for retrieval of aerosol optical properties from Sun and sky radiance measurements. Journal of Geophysical Research Atmospheres, 105(D16), 20673-20696. https://doi.org/10.1029/2000JD900282

Dubovik, O., Lapyonok, T., Litvinov, P., Herman, M., Fuertes, D., Ducos, F., et al. (2014). GRASP: A versatile algorithm for characterizing the atmosphere. SPIE Newsroom, 2-5. https://doi.org/10.1117/2.1201408.005558

Dubovik, O., Li, Z., Mishchenko, M. I., Tanré, D., Karol, Y., Bojkov, B., et al. (2019). Polarimetric remote sensing of atmospheric aerosols: Instruments, methodologies, results, and perspectives. Journal of Quantitative Spectroscopy and Radiative Transfer, 224, $474-511$. https://doi.org/10.1016/j.jqsrt.2018.11.024

Dubovik, O., Sinyuk, A., Lapyonok, T., Holben, B. N., Mishchenko, M., Yang, P., et al. (2006). Application of spheroid models to account for aerosol particle nonsphericity in remote sensing of desert dust. Journal of Geophysical Research Atmospheres, 111(D11), 1, D11208-34. https://doi.org/10.1029/2005JD006619

Eck, T., Holben, B., Reid, J., Dubovik, O., Smirnov, A., O'Neill, N., et al. (1999). Wavelength dependence of the optical depth of biomass burning, urban, and desert dust aerosols. Journal of Geophysical Research, 104(D24), 31333-31349. https://doi.org/10.1029/ 1999JD900923

Eck, T. F., Holben, B. N., Dubovik, O., Smirnov, A., Goloub, P., Chen, H. B., et al. (2005). Columnar aerosol optical properties at AERONET sites in central eastern Asia and aerosol transport to the tropical mid-Pacific. Journal of Geophysical Research: Atmospheres, 110, 1, n/ a-18. https://doi.org/10.1029/2004JD005274

Fan, X., Goloub, P., Deuzé, J. L., Chen, H., Zhang, W., Tanré, D., \& Li, Z. (2008). Evaluation of PARASOL aerosol retrieval over North East Asia. Remote Sensing of Environment, 112(3), 697-707. https://doi.org/10.1016/j.rse.2007.06.010 
Giles, D., Sinyuk, A., Sorokin, M., Schafer, J., Smirnov, A., Slutsker, I., et al. (2019). Advancements in the aerosol robotic network (AERONET) Version 3 database-Automated near-real-time quality control algorithm with improved cloud screening for Sun photometer aerosol optical depth (AOD) measurements. Atmospheric Measurement Techniques, 12(1), 169-209. https://doi.org/10.5194/amt12-169-2019

Ginoux, P., Prospero, J. M., Gill, T. E., Hsu, N. C., \& Zhao, M. (2012). Global-scale attribution of anthropogenic and natural dust sources and their emission rates based on MODIS Deep Blue aerosol products. Reviews of Geophysics, 50(RG3005), 1-36. https://doi.org/10.1029/ 2012RG000388

Goloub, P., Chepfer, H., Herman, M., Brogniez, G., \& Parol, F. (1997). Use of polarization for cloud studies. In D. H. Goldstein \& R. A. Chipman (Eds.), Polarization: Measurement, analysis, and remote sensing, Published in SPIE Proceedings (Vol. 3121, pp. 330-341). https://doi.org/10.1117/12.283865

Goloub, P., Herman, M., Chepfer, H., Riedi, J., Brogniez, G., Couvert, P., \& Sèze, G. (2000). Cloud thermodynamic phase classification from the POLDER spaceborne instrument. Journal of Geophysical Research, 105(D11), 14747-14759. https://doi.org/10.1029/1999JD901183

Hansen, J., Sato, M., \& Ruedy, R. (1997). Radiative forcing and climate response. Journal of Geophysical Research: Atmospheres, 102(D6), 6831-6864. https://doi.org/10.1029/96JD03436

Hasekamp, O. P., \& Landgraf, J. (2005). Retrieval of aerosol properties over the ocean from multispectral single-viewing-angle measurements of intensity and polarization: Retrieval approach, information content, and sensitivity study. Journal of Geophysical Research, 110(D20), 1, D20207-16. https://doi.org/10.1029/2005JD006212

Hauser, A., Oesch, D., Foppa, N., \& Wunderle, S. (2005). NOAA AVHRR derived aerosol optical depth over land. Journal of Geophysical Research: Atmospheres, 110, D08204. https://doi.org/10.1029/2004JD005439

Holben, B. N., Eck, T. F., Slutsker, I., Tanré, D., Buis, J. P., Setzer, A., et al. (1998). AERONET-A federated instrument network and data archive for aerosol characterization. Remote Sensing of Environment, 66(1), 1-16. https://doi.org/10.1016/S0034-4257(98)00031-5

Holben, B. N., Tanré, D., Smirnov, A., Eck, T. F., Slutsker, I., Abuhassan, N., et al. (2001). An emerging ground-based aerosol climatology: Aerosol optical depth from AERONET. Journal of Geophysical Research Atmospheres, 106(D11), 12067-12097. https://doi.org/10.1029/ 2001JD900014

Kaskaoutis, D. G., Rashki, A., Houssos, E. E., Mofidi, A., Goto, D., Bartzokas, A., et al. (2015). Meteorological aspects associated with dust storms in the Sistan region, southeastern Iran. Climate Dynamics, 45(1-2), 407-424. https://doi.org/10.1007/s00382-014-2208-3

Kaufman, Y. J., Boucher, O., Tanré, D., Chin, M., Remer, L. A., \& Takemura, T. (2005). Aerosol anthropogenic component estimated from satellite data. Geophysical Research Letters, 32, 1-4. https://doi.org/10.1029/2005GL023125

Kokhanovsky, A. A., Deuzé, J. L., Diner, D. J., Dubovik, O., Ducos, F., Emde, C., et al. (2010). The inter-comparison of major satellite aerosol retrieval algorithms using simulated intensity and polarization characteristics of reflected light. Atmospheric Measurement Techniques, 3(4), 909-932. https://doi.org/10.5194/amt-3-909-2010

Lee, J., Kim, J., Song, C. H., Kim, S. B., Chun, Y., Sohn, B. J., \& Holben, B. N. (2010). Characteristics of aerosol types from AERONET sunphotometer measurements. Atmospheric Environment, 44(26), 3110-3117. https://doi.org/10.1016/j.atmosenv.2010.05.035

Lee, K., \& Chung, C. E. (2013). Observationally-constrained estimates of global fine-mode AOD. Atmospheric Chemistry and Physics, 13(5), 2907-2921. https://doi.org/10.5194/acp-13-2907-2013

Leeuw, G., Holzer-Popp, T., Bevan, S., Davies, W. H., Descloitres, J., Grainger, R. G., et al. (2015). Evaluation of seven European aerosol optical depth retrieval algorithms for climate analysis. Remote Sensing of Environment, 162, 295-315. https://doi.org/10.1016/j. rse.2013.04.023

Levy, R. C., Remer, L. A., Kleidman, R. G., Mattoo, S., Ichoku, C., Kahn, R., \& Eck, T. F. (2010). Global evaluation of the Collection 5 MODIS dark-target aerosol products over land. Atmospheric Chemistry and Physics, 10(21), 10399-10420. https://doi.org/10.5194/acp10-10399-2010

Li, L., Che, H., Derimian, Y., Dubovik, O., Schuster, G. L., Chen, C., et al. (2020). Retrievals of fine mode light-absorbing carbonaceous aerosols from POLDER/PARASOL observations over East and South Asia. Remote Sensing of Environment, accepted., $247,111913$. https://doi.org/10.1016/j.rse.2020.111913

Li, L., Dubovik, O., Derimian, Y., Schuster, G. L., Lapyonok, T., Litvinov, P., et al. (2019). Retrieval of aerosol components directly from satellite and ground-based measurements. Atmospheric Chemistry and Physics, 19(21), 13409-13443. https://doi.org/10.5194/acp-19$13409-2019$

Li, Z., Gu, X., Wang, L., Li, D., Xie, Y., Li, K., et al. (2013). Aerosol physical and chemical properties retrieved from ground-based remote sensing measurements during heavy haze days in Beijing winter. Atmospheric Chemistry and Physics, 13(20), 10171-10183. https://doi. org/10.5194/acp-13-10171-2013

Li, Z., Hou, W., Hong, J., Zheng, F., Luo, D., Wang, J., et al. (2018). Directional polarimetric camera (DPC): Monitoring aerosol spectral optical properties over land from satellite observation. Journal of Quantitative Spectroscopy and Radiative Transfer, 218, 21-37. https:// doi.org/10.1016/j.jqsrt.2018.07.003

Li, Z., Li, L., Zhang, F., Li, D., Xie, Y., \& Xu, H. (2015). Comparison of aerosol properties over Beijing and Kanpur: Optical, physical properties and aerosol component composition retrieved from 12 years ground-based Sun-sky radiometer remote sensing data. Journal of Geophysical Research: Atmospheres, 120(4), 1520-1535. https://doi.org/10.1002/2014JD022593

Li, Z., Zhao, X., Kahn, R., Mishchenko, M., Remer, L., Lee, K. H., et al. (2009). Uncertainties in satellite remote sensing of aerosols and impact on monitoring its long-term trend: A review and perspective. Annales Geophysicae, 27(7), 2755-2770. https://doi.org/10.5194/ angeo-27-2755-2009

Litvinov, P., Hasekamp, O., \& Cairns, B. (2011). Models for surface reflection of radiance and polarized radiance: Comparison with airborne multi-angle photopolarimetric measurements and implications for modeling top-of-atmosphere measurements. Remote Sensing of Environment, 115(2), 781-792. https://doi.org/10.1016/j.rse.2010.11.005

Marlier, M. E., Defries, R. S., Voulgarakis, A., Kinney, P. L., Randerson, J. T., Shindell, D. T., et al. (2012). El Niño and health risks from landscape fire emissions in Southeast Asia. Nature Climate Change, 3(2), 131-136. https://doi.org/10.1038/nclimate1658

Middleton, N. J. (1986a). A geography of dust storms in south-west Asia. Journal of Climatology, 6(2), 183-196. https://doi.org/10.1002/ joc. 3370060207

Middleton, N. J. (1986b). Dust storms in the Middle East. Journal of Arid Environments, 10(2), 83-96. https://doi.org/10.1016/S01401963(18)31249-7

Mishchenko, M. I., \& Geogdzhayev, I. V. (2007). Satellite remote sensing reveals regional tropospheric aerosol trends. Optics Express, 15(12), 7423-7438. https://doi.org/10.1364/OE.15.007423

Nan, Y., \& Wang, Y. (2018). De-coupling interannual variations of vertical dust extinction over the Taklimakan desert during 2007-2016 using CALIOP. Science of the Total Environment, 633, 608-617. https://doi.org/10.1016/j.scitotenv.2018.03.125 
O’Neill, N. T., Dubovik, O., \& Eck, T. F. (2001). Modified Ångström exponent for the characterization of submicrometer aerosols. Applied Optics, 40(15), 2368-2375. https://doi.org/10.1364/AO.40.002368

O’Neill, N. T., Eck, T. F., Smirnov, A., Holben, B. N., \& Thulasiraman, S. (2003). Spectral discrimination of coarse and fine mode optical depth. Journal of Geophysical Research, 108(D17), 4559. https://doi.org/10.1029/2002JD002975

Parol, F., Buriez, J., Vanbauce, C., Couvert, P., Sèze, G., Goloub, P., \& Cheinet, S. (1999). First results of the POLDER "Earth radiation budget and clouds" operational algorithm. IEEE Transaxtions on Geoscience and Remote Sensing, 37(3), 1597-1612. https://doi.org/ $10.1109 / 36.763273$

Pope, C. A., Burnet, R. T., Thun, M. J., Calle, E. E., Krewski, D., Ito, K., \& Thurston, G. D. (2002). Lung cancer, cardiopulmonary mortality, and long-term exposure to fine particulate air pollution. Journal of the American Medical Association, 287(9), 1132-1141. https://doi.org/ 10.1001/jama.287.9.1132

Pope, C. A., Burnett, R. T., Thurston, G. D., Thun, M. J., Calle, E. E., Krewski, D., \& Godleski, J. J. (2004). Cardiovascular mortality and long-term exposure to particulate air pollution. Circulation, 109(1), 71-77. https://doi.org/10.1161/01.CIR.0000108927.80044.7F

Popp, T., Dde Leeuw, G., Bingen, C., Brühl, C., Capelle, V., Chedin, A., et al. (2016). Development, production and evaluation of aerosol climate data records from European satellite observations (Aerosol_cci). Remote Sensing, 8(5), 421. https://doi.org/10.3390/rs8050421

Qian, Y., \& Giorgi, F. (2000). Regional climatic effects of anthropogenic aerosols? The case of southwestern China. Geophysical Research Letters, 27(21), 3521-3524. https://doi.org/10.1029/2000GL011942

Ramanathan, V., Crutzen, P. J., Lelieveld, J., Mitra, A. P., Althausen, D., Anderson, J., et al. (2001). Indian Ocean Experiment: An integrated analysis of the climate forcing and effects of the great Indo-Asian haze. Journal of Geophysical Research Atmospheres, 106(D22), 28371-28398. https://doi.org/10.1029/2001JD900133

Rashki, A., Kaskaoutis, D. G., Francois, P., Kosmopoulos, P. G., \& Legrand, M. (2015). Dust-storm dynamics over Sistan region, Iran: Seasonality, transport characteristics and affected areas. Aeolian Research, 16, 35-48. https://doi.org/10.1016/j.aeolia.2014.10.003

Ren, H., Lu, B., Wan, J., Tian, B., \& Zhang, P. (2018). Identification standard for ENSO events and its application to climate monitoring and prediction in China. Journal of Meteorological Research, 32(6), 923-936. http://doi.org/10.1007/s13351-018-8078-6

Schuster, G. L., Dubovik, O., \& Arola, A. (2016). Remote sensing of soot carbon-Part 1: Distinguishing different absorbing aerosol species. Atmospheric Chemistry and Physics, 16(3), 1565-1585. https://doi.org/10.5194/acp-16-1565-2016

Schuster, G. L., Dubovik, O., Holben, B. N., \& Clothiaux, E. E. (2005). Inferring black carbon content and specific absorption from Aerosol Robotic Network (AERONET) aerosol retrievals. Journal of Geophysical Research, 110, D10S17. https://doi.org/10.1029/ 2004JD004548

Schuster, G. L., Lin, B., \& Dubovik, O. (2009). Remote sensing of aerosol water uptake. Geophysical Research Letters, 36, n/a. https://doi.org/ 10.1029/2008GL036576

Seinfeld, J. H., Carmichael, G. R., Arimoto, R., Conant, W. C., Brechtel, F. J., Bates, T. S., et al. (2004). ACE-ASIA: Regional climatic and atmospheric chemical effects of Asian dust and pollution. Bulletin of the American Meteorological Society, 85(3), 367-380. https://doi.org/ 10.1175/BAMS-85-3-367

Streets, D. G., Yarber, K. F., Woo, J.-H., \& Carmichael, G. R. (2003). Biomass burning in Asia: Annual and seasonal estimates and atmospheric emissions. Global Biogeochemical Cycles, 17(4), 1099. https://doi.org/10.1029/2003GB002040

Tang, Y., Carmichael, G. R., Woo, J.-H., Thongboonchoo, N., Kurata, G., Uno, I., et al. (2003). Influences of biomass burning during the Transport and Chemical Evolution Over the Pacific (TRACE-P) experiment identified by the regional chemical transport model. Journal of Geophysical Research: Atmospheres, 108(D21), 8824. https://doi.org/10.1029/2002JD003110

Uno, I., Carmichael, G. R., Streets, D., Satake, S., Takemura, T., Woo, J.-H., et al. (2003). Analysis of surface black carbon distributions during ACE-Asia using a regional-scale aerosol model. Journal of Geophysical Research, 108(D23), 8636. https://doi.org/10.1029/ 2002JD003252

Vanbauce, C., Buriez, J., Parol, F., \& Bonnel, B. (1998). Apparent pressure derived from ADEOS-POLDER observations in the oxygen A-band over ocean. Geophysical Research Letters, 25(16), 3159-3162. https://doi.org/10.1029/98GL02324

Wang, L., Li, Z., Tian, Q., Ma, Y., Zhang, F., Zhang, Y., et al. (2013). Estimate of aerosol absorbing components of black carbon, brown carbon, and dust from ground-based remote sensing data of sun-sky radiometers. Journal of Geophysical Research Atmospheres, 118(12), 6534-6543. https://doi.org/10.1002/jgrd.50356

Waquet, F., Cairns, B., Knobelspiesse, K., Chowdhary, J., Travis, L. D., Schmid, B., \& Mishchenko, M. I. (2009). Polarimetric remote sensing of aerosols over land. Journal of Geophysical Research Atmospheres, 114(D1), 1-23. https://doi.org/10.1029/2008JD010619

Waquet, F., Goloub, P., Deuzé, J. L., Léon, J. F., Auriol, F., Verwaerde, C., et al. (2007). Aerosol retrieval over land using a multiband polarimeter and comparison with path radiance method. Journal of Geophysical Research Atmospheres, 112(D11), 1, D11214-13. https:// doi.org/10.1029/2006JD008029

Wei, Y., Li, Z., Zhang, Y., Chen, C., Dubovik, O., Zhang, Y., et al. (2020). Validation of POLDER GRASP aerosol optical retrieval over China using SONET observations. Journal of Quantitative Spectroscopy \& Radiative Transfer, 246, 106931. https://doi.org/10.1016/j. jqsrt.2020.106931

Woo, J.-H., Streets, D. G., Carmichael, G. R., Tang, Y., Yoo, B., Lee, W.-C., et al. (2003). Contribution of biomass and biofuel emissions to trace gas distributions in Asia during the TRACE-P experiment. Journal of Geophysical Research: Atmospheres, 108(D21), 8812. https:// doi.org/10.1029/2002JD003200

Xia, X., Chen, H., Wang, P., Zhang, W., Goloub, P., Chatenet, B., et al. (2006). Variation of column-integrated aerosol properties in a Chinese urban region. Journal of Geophysical Research, 111(D5), 1, D05204-10. https://doi.org/10.1029/2005JD006203

Xia, X., Chen, H., Wang, P., Zong, X., Qiu, J., \& Philippe, G. (2005). Aerosol properties and their spatial and temporal variations over North China in spring 2001. Tellus, 57B, 28-39.

Yan, X., Li, Z., Luo, N., Shi, W., Zhao, W., Yang, X., et al. (2019). An improved algorithm for retrieving the fine-mode fraction of aerosol optical thickness. Part 2: Application and validation in Asia. Remote Sensing of Environment, 222, 90-103. https://doi.org/10.1016/j. rse.2018.12.012

Yan, X., Li, Z., Shi, W., Luo, N., Wu, T., \& Zhao, W. (2017). An improved algorithm for retrieving the fine-mode fraction of aerosol optical thickness, Part 1: Algorithm development. Remote Sensing of Environment, 192, 87-97. https://doi.org/10.1016/j.rse.2017. 02.005

Zeng, S., Parol, F., Riedi, J., Cornet, C., \& Thieuleux, F. (2011). Examination of POLDER/PARASOL and MODIS/Aqua cloud fractions and properties representativeness. Journal of Climate, 24(16), 4435-4450. https://doi.org/10.1175/2011JCLI3857.1

Zhang, C., Liu, C., Chan, K. L., Hu, Q., Liu, H., Li, B., et al. (2020). First observation of tropospheric nitrogen dioxide from the Environmental Trace Gases Monitoring Instrument onboard the GaoFen-5 satellite. Light: Science \& Applications, 9(1), 66. https://doi. org/10.1038/s41377-020-0306-z 
Zhang, C., Liu, C., Hu, Q., Cai, Z., Su, W., Xia, C., et al. (2019). Satellite UV-Vis spectroscopy: Implications for air quality trends and their driving forces in China during 2005-2017. Light: Science \& Applications, 8(1), 100. https://doi.org/10/1038/s41377-019-0210-6, https:// doi.org/10.1038/s41377-019-0210-6

Zhang, X. Y., Wang, Y. Q., Niu, T., Zhang, X. C., Gong, S. L., Zhang, Y. M., \& Sun, J. Y. (2012). Atmospheric aerosol compositions in China: Spatial/temporal variability, chemical signature, regional haze distribution and comparisons with global aerosols. Atmospheric Chemistry and Physics, 12(2), 779-799. https://doi.org/10.5194/acp-12-779-2012

Zhang, X. Y., Wang, Y. Q., Zhang, X. C., Guo, W., \& Gong, S. L. (2008). Carbonaceous aerosol composition over various regions of China during 2006. Journal of Geophysical Research Atmospheres, 113(D14), 1, D14111-10. https://doi.org/10.1029/2007JD009525 